\title{
Apreciações acerca do tráfico interno de escravos no oeste da Província de São Paulo (Rio Claro, 1861-1869).
}

- Journal of Economic Literature (JEL) Classification System: N - Economic History - N3 - Labor and Consumers, Demography, Education, Health, Welfare, Income, Wealth, Religion, and Philanthropy - N36 - Latin America; Caribbean. ANPEC: Área 2 - História Econômica.

Gabriel Almeida Antunes Rossini ${ }^{1}$

Cantagalo é um inferno, / Onde negro vai pena, / Não me venda meu sinhô, / Não me venda para lá. Catarina minha negra, / Teu senhor quer te vender, / Para o Rio de Janeiro, / Para nunca mais te ver. Coletado por Afonso d'E. Taunay, que ouviu estes versos de D. Beatriz Taques Horta.

E a cativa desgraçada / Deita seu filho, calada, / E põe-se triste a beijá-lo, / Talvez temendo que o dono / Não viesse, em meio do sono, / De seus braços arrancá-lo! A canção do africano - Castro Alves.

\section{Resumo:}

Este artigo aborda aspectos da dinâmica do comércio interno de escravos ao longo dos anos que perpassam o intervalo 1861-1869. Empreendemos esta investigação a partir da análise de 320 Escrituras que registraram a compra-venda de 575 cativos, em Rio Claro, município pertencente ao oeste da província de São Paulo que, naquele período, vivenciou os momentos iniciais da expansão 'leste-oeste' dos cafeeiros na chamada zona paulista. Com base no referido núcleo documental, realizamos apreciações econômicas e demográficas dos indivíduos que sofreram o fado das diferentes modalidades deste comércio. Além da introdução e das considerações finais, o texto é formado por outras quatro partes, quais sejam: no segundo e terceiro itens discutimos, respectivamente, o recorte espacial e temporal; em seguida, abordamos as fontes primárias que tivemos acesso nos arquivos cartoriais da cidade em apreço; por fim, tratamos, mais detidamente, das diferentes informações constantes nestas Escrituras.

Palavras chave: Tráfico de escravos, Café, Oeste-paulista.

\begin{abstract}
:
This article focuses on the dynamics of the internal slave trade over the years that pass through the interval 1861-1869. We undertook this investigation from the analysis of 320 Scriptures that recorded the purchase-sale of 575 slaves in Rio Claro, a municipality belonging to the western province of São Paulo that, at the period, experienced the early stages of expansion 'eastwest' of coffee trees in the area called Paulista. Based on this core document, perform economic and demographic assessments of individuals who suffered the misfortune of the different forms of trade. Besides the introduction and final consideration, the text is formed by four other parties, namely: the second and third items discuss, respectively, the spatial and temporal clipping, then approach the primary sources that had access to the notarial archives of the city under consideration, and finally treat, in more detail, the different information contained in these Scriptures.
\end{abstract}

Keywords: Slave traffic, Coffe, West Paulista.

\section{Introdução}

A produção de café no Brasil se firma a partir dos anos vinte do século XIX. A partir da década de 1870 e, sobretudo, a partir de 1880 , quando a produção média ultrapassa os 5 milhões de sacas por ano, o café torna-se o centro motor do desenvolvimento do capitalismo no Brasil ${ }^{2}$.

Inicialmente, as plantações de café estenderam-se pelo vale do Paraíba fluminense e paulista, assim sendo, ocuparam a porção ocidental da província do Rio de Janeiro e, em seguida, o chamado norte paulista. Continuando a sua marcha ascendente, fundada na incorporação de amplos espaços, houve expansão dos cafezais na província de Minas Gerais (zona da mata e sul do Estado) e Espírito Santo, ao mesmo tempo em que a produção consolidou-se no interior de São Paulo. Nos anos iniciais da década de 1860, os cafezais avançaram pela Mantiqueira paulista (Mococa, Pardo, Atibaia e Bragança Paulista) e estabeleceram contato com os arbustos que vinham do sul de Minas Gerais ${ }^{3}$.

\footnotetext{
${ }^{1}$ Doutorando IE-UNICAMP. E-MAIL: gaarossini@gmail.com

${ }^{2}$ Silva, Sergio. Expansão cafeeira e origens da indústria no Brasil. São Paulo: Alfa-Omega, 1986, pág. 43.

${ }^{3}$ Cf. PRADO JUNIOR, Caio. História Econômica do Brasil. São Paulo: Editora Brasiliense, 2006 ; COSTA, Emília Viotti da. Da Senzala à Colônia. São Paulo: Unesp, 1998; FURTADO, Op. Cit. Com o espraiamento do café pelo chamado norte paulista, a província empenhada, até então, em plantações de cana de açúcar pouco competitivas em relação às do nordeste passou a vivenciar novos tempos. Tal como observado pela professora Alice Canabrava: "temos na atividade açucareira a formação histórica que marcou e condicionou o início das plantações cafeeiras. A economia cafeeira não apenas se apropriou das características estruturais e de funcionamento herdadas da açucareira assim como as superou. Pode-se dizer que a transição da cultura da cana para a do café, iniciada nos anos 1830, consolidou-se nas décadas de 1850 e 1860 ". Cf. CANABRAVA, Alice P., "Esboço da história econômica de São Paulo". In: BRUNO, Ernani Silva (org.), São Paulo Terra e Povo. Porto Alegre: Globo, 1967. Ver também: PETRONE, Maria Thereza Schorer, A lavoura canavieira em São Paulo: expansão e declínio (1765-1851). São Paulo, Difusão Européia do Livro, 1968. João Manuel Cardoso de Mello enfatiza que: "Inúmeras fazendas de café foram organizadas com capitais transferidos diretamente do setor mercantil (comércio de mulas, capital usurário urbano, tráfico de escravos etc.)" MELLO, João Manuel Cardoso de. O Capitalismo Tardio: Contribuição à revisão crítica da formação e do desenvolvimento da economia brasileira. São Paulo: Editora Brasiliense, 1986, pg. 54.
} 
Os últimos vinte anos do Império marcaram, por um lado, a crise da cafeicultura em toda a extensão do vale do Paraíba - em virtude do empobrecimento do solo e queda da produtividade, consequência de uma exploração descuidada e extensiva, os cafezais tornaram-se decadentes; temos aí: "rendimentos decrescentes, enfraquecimento das plantas, aparecimento de pragas destruidoras, abandono sucessivo das culturas e rarefação demográfica" ${ }^{4}$ - e, por outro, um acentuado desenvolvimento da lavoura cafeeira no chamado oeste paulista ${ }^{5}$, até então região pobre e quase deserta. Suas terras devolutas foram rapidamente invadidas pela nova cultura. Podemos acompanhar este processo, em grandes traços, por meio de uma marcante passagem do relatório intitulado $O$ Brasil, Suas Riquezas Naturais, Suas Indústrias, escrito em 1907.

Ate hoje, porem, a regra tem sido a lucta, sem tregoas, entre o cafezal e a floresta. Para cada cafezal que se pretende formar, penetram, desapiedados, o machado e o fogo na verdejante floresta, por sobre as ruinas da qual surge aquelle, em seguida, contrastando o seu viço e belleza com os despojos encarquilhados desta, symbolos sinistros da irnprevidencia humana ${ }^{6}$.

Sem dúvida, a expansão agrícola de São Paulo, a partir do início da segunda metade do século XIX, é um dos mais expressivos acontecimentos da história econômica do Brasil. O oeste da província de São Paulo, que fora um território relativamente marginalizado, com escassas vias de comunicação adequadas e com parca população economicamente ativa transformou-se no centro dinâmico da economia brasileira ${ }^{7}$. Em virtude da expansão dos cafezais a província assumiu o primeiro lugar na produção brasileira de café, superando Minas Gerais (1881) e a Província do Rio de Janeiro (1889). Neste momento, o espaço geográfico "que se abre em leque desde Campinas para o Noroeste, alcançando Rio Claro e estendendo-se até Bauru e Ribeirão Preto"8 ganhou novos contornos e características tornando-se uma das principais bases geoeconômicas da sociedade brasileira de então.

O dinamismo do café em São Paulo mostrou, já no último quarto do século XIX, que outra economia se formara no país: a do complexo cafeeiro capitalista paulista. ${ }^{9}$ Destarte, observamos em terras paulistas, na segunda metade do XIX, a conformação de um intrincado mosaico de

\footnotetext{
${ }^{4}$ VANGELISTA, Chiara. Os braços da lavoura: imigrantes e caipiras na formação do mercado de trabalho paulista (1850-1930). São Paulo: Hucitec/Instituto Italiano de Cultura, 1991. Pág. 23. Ou tal como Lobato nos diz: "Por ela passou o Café, como um Atila. Toda a seiva foi bebida e, sob forma de grão, ensacada e mandada para fora. Mas do ouro que veio em troca nem uma onça permaneceu ali, empregada em restaurar a torrão. Transfiltrou-se para o Oeste, na avidez de novos assaltos a virgindade da terra nova; ou se transfez nos palacetes em ruína; ou reentrou na circulação europeia par moa de herdeiros dissipados". Lobato, M. Cidades Mortas, em Cidades Mortas. São Paulo: Brasiliense, 1995. p. 23.

5 Emília Viotti da Costa identifica como "zonas relativamente novas" do oeste paulista, municípios: "Rio Claro, Araras, Jabuticabal, Araraquara, Descalvado, Limeira, São Carlos (...) cujo desenvolvimento fora posterior a 1850". Esses municípios mantinham, em 1886, um índice de população escrava (12,9\%), superior ao das zonas mais antigas, como o Vale do Paraíba e o oeste paulista mais antigo [região de Campinas] que, nessa época, apresentavam, respectivamente 8,5 e $10,5 \%$ ". Costa, E. V. Da senzala a colônia, São Paulo, Livraria Editora Ciências Humanas, 1982, p. 195.

${ }^{6}$ IBGE, Series Estatísticas Retrospectivas. O Brasil, Suas Riquezas Naturais, Suas Indústrias. Vol 2. Rio de Janeiro, 1986. Original publicado em 1908.

${ }^{7}$ Cf. LOVE, Joseph. A Locomotiva: São Paulo na Federação Brasileira (1889-1937). Rio de Janeiro: Paz e Terra, 1982. Ao longo dos anos, o Estado do Rio ficaria em posição cada vez mais secundária, sendo ultrapassado por Minas, em 1896 e pelo Espírito Santo, em 1928. SIMONSEN, Roberto. Aspectos da História Econômica do café. Evolução industrial do Brasil e outros estudos. São Paulo: Cia Ed. Nacional, 1973. Pág. 190.

${ }^{8}$ DEAN, Warren, Rio Claro, um sistema de grande lavoura: 1820-1920. Rio de Janeiro: Paz e Terra, 1977. Pág. 13.

${ }^{9}$ CANO, Wilson. "Padrões diferenciados das principais regiões cafeeiras (1850-1930)". Estudos Econômicos. São Paulo IPE/USP, v. 15, n. 2, maio/agosto, 1985:291-306. Pág. 294. João Manuel C. Mello, na mesma linha, indica que "o capital cafeeiro é, ao mesmo tempo, agrário, industrial e mercantil, e que convém pensar num complexo exportador cafeeiro, integrado por um núcleo produtivo, que inclui as atividades de beneficiamento, e por um segmento urbano, que acolhe os serviços de transportes (estradas de ferro, portos, etc.), as atividades comerciais (casas importadoras e exportadoras) e financeiras (bancos). Deste ponto de vista, a acumulação cafeeira é, em grande medida, acumulação urbana, que absorveu boa parte da força de trabalho imigrante e exigiu a importação de meios de produção (trilhos, materiais de construção, equipamentos ferroviário, portuário etc.). MELLO, J.M.C. Op. Cit. pág. 128-129. Ver também: SILVA, Sergio, Expansão cafeeira e origens da indústria no Brasil, São Paulo: Alfa-Ômega, 1976. Grosso modo, durante as décadas de 1860-1880, os fatores que transformaram o planalto paulista no centro dinâmico da economia brasileira foram vários, vejamos: a abundância de terras aráveis, apropriadas para o cultivo do café, possibilitado pela expansão da rede de ferrovias que deslocou continuamente a fronteira produtiva paulista; a transição do trabalho escravo para o trabalho livre e a entrada de trabalhadores imigrantes; o estabelecimento de contratos que favoreceram a expansão dos cafeeiros; a simultânea elevação na demanda mundial por café (enquanto em 1840 foram exportadas cerca de 10 milhões de sacas de $60 \mathrm{Kg}$, em 1860, exportou-se quase 30 e em 1890, perto de 50 ) e a capacidade das elites econômica e política paulistas para desenhar e implementar políticas para manter o preço do café durante períodos de largas flutuações dos preços etc. Cf. Martins e Johntson. 150 anos de café. São Paulo: Salamandra Consultoria Editorial, 1992. p. 324; Cf. HOLLOWAY, T. Condições do Mercado de trabalho e Organização do Trabalho nas Plantações na Economia Cafeeira de São Paulo, 1885-1915. In. Estudos Econômicos, IPE São Paulo. V.2, N. 6, 1972
} 
acontecimentos, muitos dos quais já largamente tratados pela literatura conexa. Vários destes trabalhos deixaram às claras a amplitude das transformações ocorridas, possibilitando, hoje, bom conhecimento acerca do desenho multifacetado resultante da história do café no Brasil e, em particular, em São Paulo. Deste modo, temos boas informações disponíveis sobre as feições de sua economia e geografia, da sociedade peculiar que criou, do exercício do poder político por parte daqueles que dispunham dos meios de produção, comercialização e financiamento vinculados ao café, da cultura popular e erudita que nele se inspirou etc. Talvez, sobre nenhuma outra mercadoria brasileira tenha sido derramada tanta tinta.

No âmbito desta multiplicidade de elementos que perpassam o assunto café e sua expansão, o mote do comércio interno de cativos, pós-1850, constitui ponto essencial e ainda insuficientemente explorado $^{10}$. O presente trabalho inscreve-se nesta linha de investigação. Deste modo, aqui, nós nos debruçamos sobre o contexto configurado pela impossibilidade da continuação do tráfico atlântico (África-Brasil), em virtude da enérgica perseguição inglesa aos "nautas de todas as plagas ${ }^{11}$ " a proa de seus tumbeiros, que se intensificou em 1849 e $1851^{12}$.

Mais especificamente, objetivamos investigar algumas características do tráfico interno de escravos, tendo como contexto o problema da inelasticidade da mão-de-obra - "problema nacional básico"13 -, enfrentado pelos fazendeiros, ocasionado, em grande medida, pela marcha ascendente da rubiácea, nas terras para lá de Campinas, que procuramos, em grandes traços, delinear nos parágrafos acima e pela extinção do tráfico transatlântico de escravos sem que se conjecturasse uma solução alternativa. Assim sendo, aqui nós nos dedicaremos à análise de aspectos de um comércio que se reveste de importância ímpar, pois: (i) abasteceu continuamente o oeste da província de São Paulo, que teve como fator de produção preponderante até meados dos anos 1880, o trabalho compulsório; (ii) teve caráter específico, não se configurando "mero substituto" do tráfico atlântico, mas "sua continuação ${ }^{14}$; (iii) "contribuiu fortemente para acelerar a abolição da escravidão no Brasil" - como afirmou, de forma contundente, Richard Graham ${ }^{15}$ - e; (iv) foi apontado como fundamental para a manutenção do caráter centralizado do império brasileiro ${ }^{\mathbf{1 6}}$.

Uma vez que o governo brasileiro, acossado pelos ingleses, suprimiu esta mercancia ultramarina no começo dos anos 1850, os escravistas passaram a disputar somente os cativos disponíveis nas várias regiões do território nacional. Cenário que acentuou largamente o fluxo de escravos das regiões menos prósperas ou decadentes em direção à região mais próspera, ou seja, às

\footnotetext{
${ }^{10} \mathrm{O}$ tráfico interno de escravos - como afirmou o professor José Flávio MOTTA - tornou-se um dos principais temas de nossas pesquisas acadêmicas desde meados dos anos de 1990. Porém, ainda são escassas as localidades nas quais os documentos "[d]esse mercado de carne humana (...) esse foco de corrupção", como falou Joaquim Nabuco, foram investigados detidamente, "ainda [que os - GR] registros cartoriais são mais acessíveis do que os historiadores anteriormente pensavam" (Graham, Richard. Nos tumbeiros mais uma vez? O comércio interprovincial de escravos no Brasil. Afro-Ásia, Salvador, n. 27, p 121-160, 2002, p. 141). Elencamos na bibliografia deste texto alguns trabalhos acerca deste tema. Motta, José Flávio. Escravos daqui, dali e de mais além. Tese de Livre Docência - FEA-USP. 2010, p. 2. Joaquim Nabuco, Discurso, 04/09/1880, in Brazil, Congresso, Câmara dos Deputados, Anais, 1880, 5, p. 36.

${ }^{11}$ Alves, Castro. O Navio Negreiro.

${ }^{12}$ Stanley J. Stein usando alguns dados de Maurício Goulart (Escravidão africana no Brasil) afirma que "a crescente atividade das patrulhas inglesas, que capturaram 90 embarcações carregadas de escravos, entre 1849 e 1851, e a consequente perda do capital investido pelos comerciantes frustraram o tráfico. O governo imperial adotou medidas efetivas para detê-lo". Stein, Stanley J. Vassouras: Um municipio brasileiro do café, 1850-1900. Rio de Janeiro: Nova Fronteira, 1990. Ver também: ABAETÉ, Antônio Paulino Limpo de Abreu, Visconde de Protesto contra o acto do Parlamento britânico, que sujeitou os navios brazileiros que fizerem o trafico de escravos ao Tribunal do Almirantado e a qualquer Tribunal de Vice-Almirantado dentro dos domínios de Sua Magestade Britannica. Rio de Janeiro : Typ. Imperial e Constitucional de Villeneuve 1845.

${ }^{13}$ Ver Furtado, C. Formação econômica do Brasil, São Paulo: Cia. Ed. Nacional, 1972, pág. 117-142.

${ }^{14}$ Robert E. Conrad, Tumbeiros: o tráfico de escravos para o Brasil, São Paulo, Brasiliense, b1985, p. 205.

${ }^{15}$ Este raciocínio se baseia no papel particularmente importante dos próprios escravos: o crescimento da resistência daqueles escravos que tinham sido arrancados de seus contextos familiares e antigos laços sociais minou a autoridade dos senhores e encorajou-os a forçar sua própria libertação através da ação direta. Graham, Richard. 2002, Op. Cit. p. 122.

${ }^{16}$ Décio Saes nos diz: "A centralização do Estado escravista não apenas evitou as abolições regionais da escravidão, como também garantiu o funcionamento do tráfico interprovincial de escravos, conveniente aos interesses das diferentes classes de proprietários de escravos: traficantes internos de escravos, senhores escravistas das áreas em declínio, plantadores escravistas das áreas em expansão". Saes, D. A formação do Estado burguês no Brasil (1888-1891). Rio de Janeiro: Paz e Terra, 1985. p. 50.
} 
áreas cafeeiras em expansão ${ }^{17}$. Processo que transformou, diga-se de passagem, as fazendas do oeste paulista no setor mais retrogrado, em virtude da ampla absorção dos escravos de outras áreas, e, ao mesmo tempo, mais progressista, em decorrência da tentativa e/ou efetiva incorporação do trabalho assalariado.

Deste modo, os escravos foram transferidos, predominantemente, da menos lucrativa produção açucareira nordestina - sobretudo, das pequenas e médias propriedades agrícolas ${ }^{18} \mathrm{e}$, também, das vilas e cidades ${ }^{19}$ - ou do sul, onde a atividade do charque estava em declínio, para os portos do Rio de Janeiro e Santos e daí, crescentemente, para o oeste da província de São Paulo.

Os dados quantitativos existentes sobre o conjunto do tráfico interno pós 1850 , são ambíguos. Não obstante, é consensual que o seu volume é menor, do que o do anterior tráfico que fazia sob o "estalar de açoite legiões de homens negros como a noite" ${ }^{20}$ dançar nos tombadilhos (cerca de 24 mil escravos foram, por ano, trazidos da África para todos os portos do Brasil, durante 1830-40).

Sebastião Ferreira Soares calculou, no ano de 1860, o número médio de escravos traficados anualmente do nordeste para o Rio de Janeiro nos anos 1850 como sendo de 3.439, e estimava em mais ou menos outros 1.500 , os que chegaram com seus proprietários ou vieram da região sul do país. Estes mesmos números são reproduzidos e corroborados por Stanley Stein em seu trabalho sobre o município de Vassouras. O Herbert Klein, por sua vez, concluiu que se forem somados, aos dados de Soares, os embarques de escravos para o porto de Santos é admissível que, nas décadas de 1850 e 1860, o número de escravos vindos do Nordeste chegasse, em média, a 5 ou 6 mil por ano ${ }^{21}$.

Outra estimativa disponível nos foi oferecida por Robert Slenes. Sobre ela, Robert Conrad nos diz que "(...) em seu detalhado estudo demográfico da população escrava do Brasil, Robert Slenes estimou que cerca de 200.000 escravos foram transportados no tráfico interprovincial entre 1850 e 1881, mas que um número muito maior foi movimentado intra-regionalmente. Se Slenes estiver certo, mais de 400.000 escravos foram vítimas desse tráfico, durante aquelas três décadas" ${ }^{22}$. Estes números, por sua vez, são próximos do montante estimado por Jacob Gorender. Este autor avaliou que os municípios cafeeiros absorveram cerca 450 mil escravos decorrentes do comércio interprovincial e intraprovincial ${ }^{23}$.

O tráfico interno de cativos envolveu, pois, número expressivo de indivíduos, essencialmente enviados para as áreas integradas à economia exportadora do sudeste. Este deslocamento humano apresentou diferenças significativas com relação à travessia atlântica com destino ao Brasil - por exemplo: as possibilidades de sobrevivência nesse trajeto foram maiores em comparação à travessia atlântica, com o passar dos anos os escravos transacionados passaram a ser preponderantemente crioulos (negros e mulatos) já aclimatados etc. ${ }^{24}$. Sem embargo, houve características análogas. Em especial, no que diz respeito ao sexo e à idade das pessoas negociadas. Estes aspectos perpetuaram, grosso modo, a mesma desproporção que marcou os contingentes provenientes das diversas localidades africanas. Esta desproporção alavancou o balanço negativo entre mortalidade e natalidade ${ }^{25}$

\footnotetext{
${ }^{17}$ Segundo W. Dean, enquanto durou o ciclo do açúcar, os escravos de Rio Claro eram (...) herdados dos pais, ou emprestado por parentes, ou talvez transferidos de outras propriedades que possuíam. As compras de escravos eram raras e ocasionais, às vezes apenas de um ou dois ao mesmo tempo; em geral os vendedores eram fazendeiros de municípios mais para o interior, onde as perspectivas para a cultura canavieira eram menos promissoras. Até o início do comércio de café, esse processo irregular foi suficiente. Dean, W. Op. Cit. p. 65.

${ }^{18}$ Os escravos enviados do Nordeste para o Sul não vinham das plantações de cana de açúcar. Pelo fato de que a exportação nordestina de açúcar não estava mais em expansão, há a falsa convicção de que eram os senhores de engenho que vendiam seus escravos para o Sul, mas não foi usualmente este o caso. Cf. Agostinho Marques Perdigão Malheiro, Discurso, 03/07/1877, in Brazil, Congresso, Câmara dos Deputados, Anais, 1877, 2, p. 23; Stanley J. Stein, Op. Cit. 95.

19 Alguns dados da província da Bahia, relativos a 1854, por exemplo, demonstram que $60 \%$ dos escravos exportados desta província vinham das vilas e cidades. Slenes, Op. Cit.. p. 134.

${ }^{20}$ Alves, Castro. O Navio Negreiro.

${ }^{21}$ Sidney Chalhoub. Op. Cit. p. 129. Ver também: José Flávio. Escravos daqui, dali e de mais além. Op. Cit. p. 53.

${ }^{22}$ Conrad, Robert. Citado por Motta, José Flávio. Escravos daqui, dali e de mais além. Op. Cit. p. 51.

${ }^{23}$ Gorender, Jocob. 1985. p. 326. Já o professor José Flávio Motta, por seu turno, em sua tese de Livre Docência, no tocante a essas distintas estimativas da quantidade de cativos comercializados internamente, após 1850, adotou as avaliações de Robert Slenes para aquele tráfico.

${ }^{24}$ Cf. Conrad, Op. Cit. p. 194-195.

${ }^{25}$ Para Rio Claro, concluiu Dean, com base no Censo de 1872, que a proporção de crianças sobreviventes de 3 a 15 anos em relação a mulheres em idade fértil era mais de três vezes maior para as mulheres livres do que para as escravas. Dean, W. Op. Cit. 72-73. Vale frisar que o crescimento vegetativo da população escrava não deve ser tornado sempre, a priori, como negativo. Por exemplo, no período 1831-32, tomando um conjunto de localidades nas quais viviam provavelmente cerca de $80 \%$ da população
} 
e patenteou, por um lado, o envelhecimento e a preponderância de escravas nas zonas que enfrentavam dificuldades e a concentração de homens jovens nas áreas mais prósperas. Estas ocorrências, aliadas ao movimento de manumissões ${ }^{26}$ acarretou acelerada queda no estoque nacional destas pessoas. Vejamos, a seguir, o percentual masculino na composição da população escrava do nordeste e centro-sul.

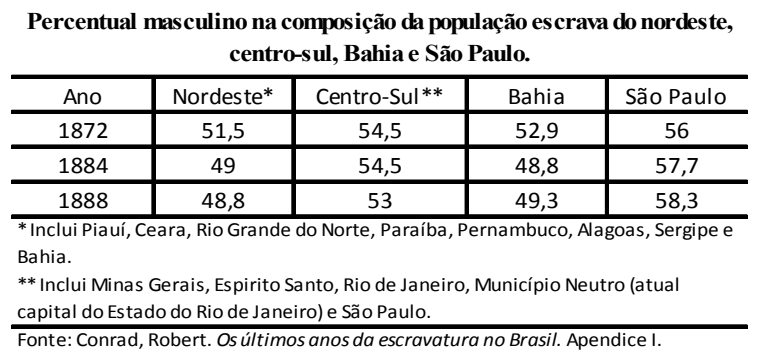

Deste modo, enquanto em $1850^{27}$ havia, aproximadamente, 2.500 .000 escravos no Brasil, em 1870 - de acordo com o recenseamento geral do Império realizado na primeira metade desta década -, o contingente de cativos era de 1.555.000, número que caiu para cerca de 700.000 , por volta de 1887 .

Por fim, três aspectos finais, quais sejam: (i) o afluxo crescente de escravos tornava a dinâmica do aparelho produtivo cafeeiro ainda mais inconstante. Estes novos contingentes que passavam a integrar a força de trabalho do sudeste vinham de regiões distantes e em geral não conheciam as práticas cafeeiras, ou mesmo qualquer trabalho agrícola; (ii) As inquietações dos fazendeiros cresciam pois, havia a impressão de que os escravos que compravam de outras províncias eram os mais difíceis e rebeldes. Na Assembleia provincial alegava-se que por isso estavam tornando-se mais frequentes crimes violentos: "Trazendo consigo o vício, a imoralidade, a insubordinação, deixam em perigo a ordem pública... assassinos e não trabalhadores, recolhem em suas casas os fazendeiros que compram escravos que vem de fora" ${ }^{28}$; (iii) o fato de os escravos existentes serem largamente disputados entre os fazendeiros do sudeste deu origem ao medo de uma nação dividida entre um sul escravocrata e um norte sem escravos. O Conselheiro J. J. Teixeira Junior advertiu seus companheiros parlamentares, em 1877, que os escravos existentes em São Paulo, Rio de Janeiro e Minas Gerais perfaziam mais do que a metade do contingente total. Três anos mais tarde, foi revelado que as 10 províncias ao sul do Espírito Santo tinham o dobro do número das 11 províncias ao norte da Bahia, aproximadamente uma relação de 920.921 para $498.268^{29}$. Após relatar estes dados J. J. Teixeira lembrou aos seus leitores que:

(...) o conflito de interesses havia colocado os grupos sem escravos no Norte dos Estados Unidos contra os fazendeiros do Sul e conduzido à imposição da emancipação, Rafael P. de Barros advertiu que, por limitações opostas no tráfico de escravos interprovincial, os representantes do Norte do Brasil na Assembleia Geral de 1880 justificavam os temores do Sul de que, uma vez que a venda dos escravos do Norte era lucrativa, eles seriam indiferentes a emancipação. Por mais forçoso que possa ter sido tal

total da província de Minas Gerais, e não obstante a presença do tráfico negreiro internacional, Paiva \& Libby (1995) corroboraram a hipótese de que a população escrava mineira se sustentava, parcialmente, mediante a reprodução natural. Por sua vez, Cano e Luna, ao criticarem as hipóteses apresentadas no trabalho de Roberto B. Martins, afirmam que tais conjecturas pecam por tentar conciliar uma estimação de enormes importações de escravos para uma economia que, no dizer do próprio autor (Martins), era escassamente mercantilizada. Cano \& Luna, A reprodução natural de escravos em Minas Gerais (século XIX): uma hipótese. Em: Ensaios sobre a formação econômica regional do Brasil. Campinas, SP: Editora da UNICAMP, 2002.

${ }^{26}$ A alforria servia aos senhores para os seguintes objetivos principais: permitia-lhes livrar-se de escravos imprestáveis, concedida como prêmio, estimulava a fidelidade de certo tipo de escravos, a exemplo dos domésticos, diante dos quais os senhores eram mais vulneráveis; constituía uma fonte de renda suplementar derivada do pecúlio dos escravos. Como é evidente, a alforria foi um fator de decréscimo da população escrava. Segundo Gorender, o padrão das alforrias no Brasil pode ser sintetizado nas seguintes características: a) maioria de alforrias onerosas e gratuitas condicionais; b) proporção relevante de alforrias gratuitas incondicionais; c) maior incidência das alforrias na escravidão urbana do que na escravidão rural; d) alforrias mais frequentes nas fases de depressão e menos frequentes nas fases de prosperidade; e) maioria de mulheres entre os alforriados, embora elas fossem minoria entre os escravos; f) elevado percentual de domésticos entre os alforriados; g) maior incidência proporcional de alforrias entre os pardos do que entre os pretos; h) elevado percentual de velhos e inválidos em geral entre os alforriados. Gorender, Op. Cit. p. $352-355$.

${ }^{27}$ Vale notarmos que, já pressentindo o fim do tráfico, os negreiros estabelecidos no Brasil tomaram a precaução de introduzir no país, somente no quadriênio 1846-1849, 220 mil africanos. Repetiam a prática da intensificação da atividade dos navios tumbeiros em 1827-1830, às vésperas da aprovação da lei que pôs o tráfico africano na ilegalidade total, em 1831. Cf. Bethell, L. págs. 70-75.

${ }^{28}$ APESP, Polícia, 23/dez/1876 citado por Dean, W. Op. Cit. p. 135.

${ }^{29}$ Stein, Op. Cit. p. 96. 
argumento, quando a assembleia provincial do Rio votou restrições ao trafico em 1881, o medo de insurreição — não emancipação inesperada - era a explicação oficia ${ }^{30}$.

Portanto, no final de 1880 e começo de 1881, foi criado - na província do Rio de Janeiro e, também, nas províncias de São Paulo e Minas Gerais - impostos de tal monta que, potencialmente, proibiam a importação de escravos de outras províncias, assim pondo fim ao tráfico interprovincial de seres humanos, no início dos anos 1880 - tendo, a sua possibilidade, sido proibido definitivamente com a Lei do Sexagenário, em 1885. Logo, no decorrer da década de 1880, tal comércio limitou-se ao deslocamento intraprovincial de cativos ${ }^{31}$.

A seguir, discorreremos, sucintamente, sobre: (i) o recorte espacial escolhido: Rio Claro; (ii) o corte temporal utilizado: 1861-1869; (iii) o núcleo documental que perpassa a investigação aqui empreendida: Escrituras de compra e venda de escravos que registraram os negócios envolvendo 575 cativos; (iv) além disso, faremos apontamentos mais detalhados acerca dos dados levantados.

\section{Recorte espacial: Rio Claro.}

Foi o caso que estando já a terra assaz povoada de filhos, filhos de filhos e filhos de netos da nossa primeira mãe e do nosso primeiro pai, uns quantos desses [...] Puseram-se a traçar uns riscos no chão, a espetar umas estacas, a levantar uns muros de pedra, depois do que anunciaram que, a partir desse momento, estava proibida (palavra nova) a entrada nos terrenos que assim ficavam delimitados sob pena de um castigo, que segundo os tempos e os costumes, poderia via a ser de morte, ou de prisão, ou de multa, ou novamente de morte. / (José Saramago, em: Sebastião Salgado, Terra).

A presente análise irá deter-se em um dos mais proeminentes centros cafeicultores do oeste paulista. O nosso estudo sobre o tráfico interno de cativos terá como locus privilegiado o município de Rio Claro. Cidade que pertence ao que José Francisco de Camargo chamou de Região da Baixa Paulista $^{32}$ e que foi, definitivamente, integrada à franja da economia exportadora paulista com sua ligação à Campinas, feita, em 1876, pela Companhia Paulista de Estrada de Ferro.

Em virtude dos dados por nós levantados acerca do tráfico de escravos e, também, dos subsídios oferecidos por Camargo, Milliet e Dean ${ }^{33}$ - acerca do número de cafeeiros, das unidades produtoras, da quantidade de arrobas produzidas, do paralelismo entre o avanço dos trilhos e a conquista de novas regiões pelo café, da entrada de trabalhadores nacionais (escravos e livres) e estrangeiros etc. - entendemos que este município configura uma amostra adequada para vislumbrarmos, no período proposto, a relação entre: a marcha ascendente da cafeicultura e a dinâmica do comércio de cativos no "oeste" de São Paulo. Vejamos a seguir, a evolução de alguns dados concernentes a certas zonas paulistas e outros específicos sobre o município que temos em apreço, pertencente a região denominada Baixa Paulista.

\footnotetext{
${ }^{30}$ Idem. p. 96. Mesmo recorrentes, estes temores devem ser ponderados diante do fato de que "na década de 1870, todos os 643 municípios do império dos quais havia estatísticas ainda continham escravos". Conrad, 1985, Citado por Motta, J. F. Op. Cit. p. 55.

${ }^{31}$ Emília Viotti da Costa, Da senzala à colônia, São Paulo, Difel, 1966, pp. 208-210;

${ }^{32}$ Cf. CAMARgo J. F. de, Crescimento Populacional no Estado de São Paulo e seus Aspectos Econômicos. Ensaio Sobre a Relação Entre Demografia e Economia. Boletim N. 153 Economia Política e História das Doutrinas Econômicas. São Paulo USP 1952. A composição municipal adotada por J. F. de Camargo - e por extensão a do presente projeto de investigação - é a que vigorava até o recenseamento de 1940. As regiões do interior de São Paulo, de acordo com Sérgio MILLIET (Roteiro do Café. São Paulo: Hucitec, 1939) e J. F. CAMARGO (1952) foram tradicionalmente definidas e batizadas pelo nome das estradas de ferro que as talhavam, em virtude do sincronismo existente entre impulso demográfico, desenvolvimento econômico e expansão da via férrea. Esta definição persiste até os dias atuais no imaginário paulista. Ao longo deste texto, mantivemos a nomenclatura regional pautada pelas estradas de ferro.

${ }^{33}$ Todos já anteriormente citados.
} 

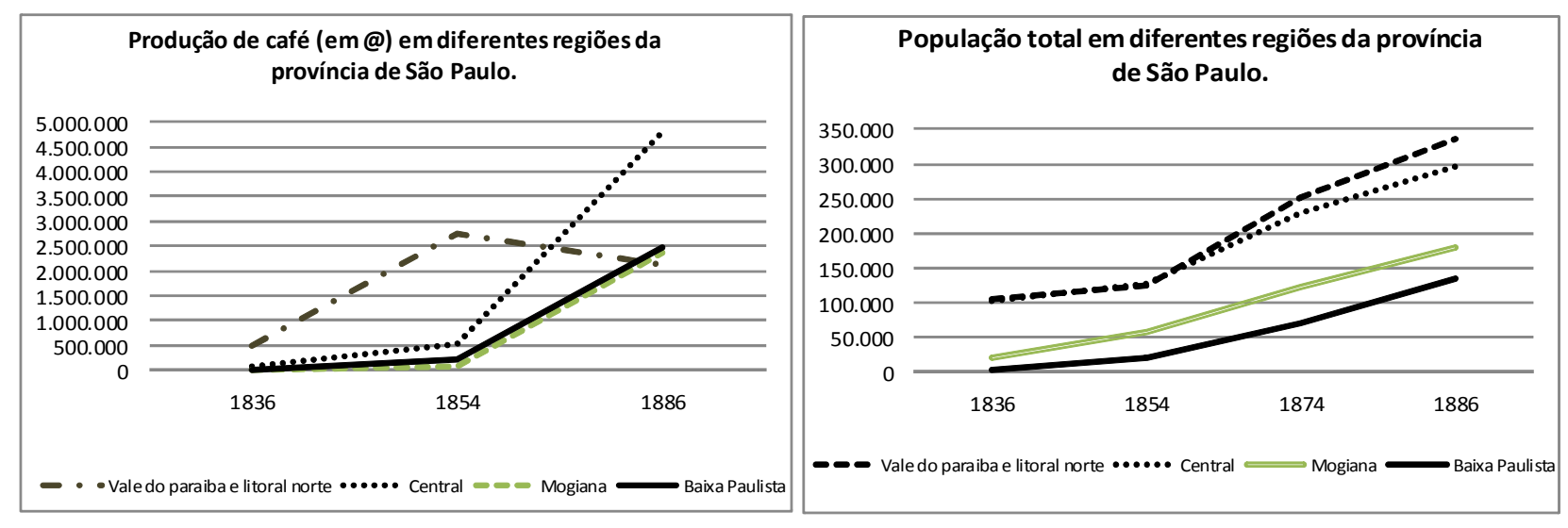

Fonte: Camargo, J. F. Op. Cit. p. 61 - 62

Fonte: Camargo, J. F. Op. Cit. p. $61-62$
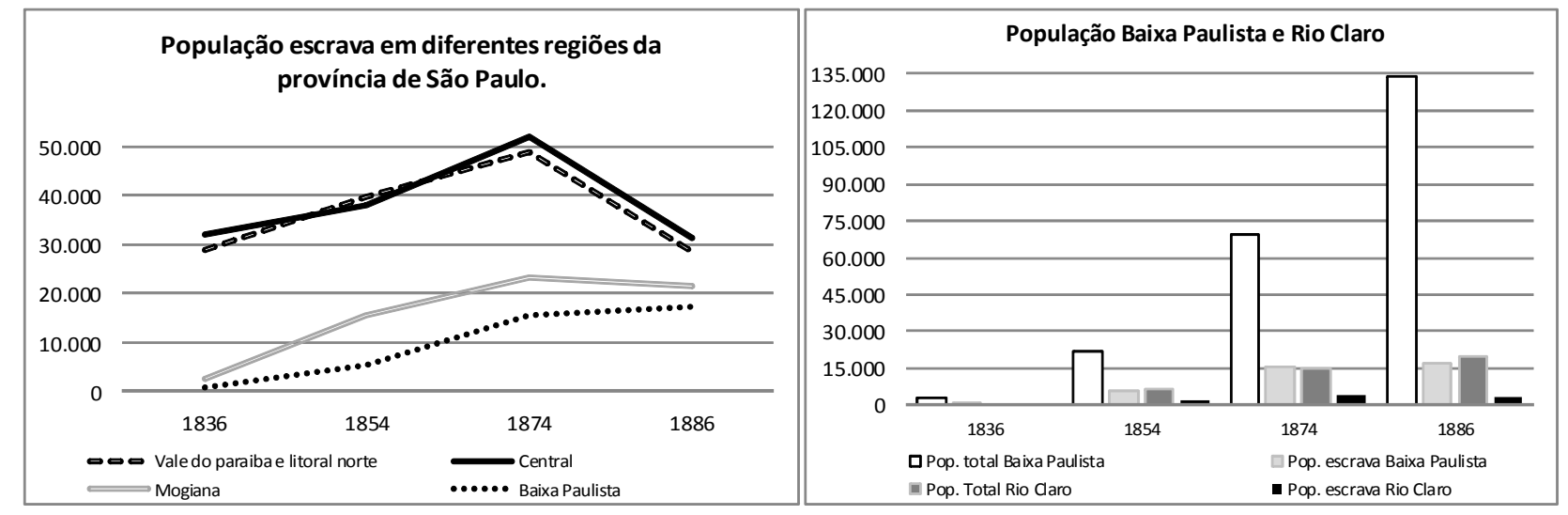

Fonte: Camargo, J. F. Op. Cit. p. 61 - 62

Fonte: Camargo, J. F. Op. Cit. p. $61-62$

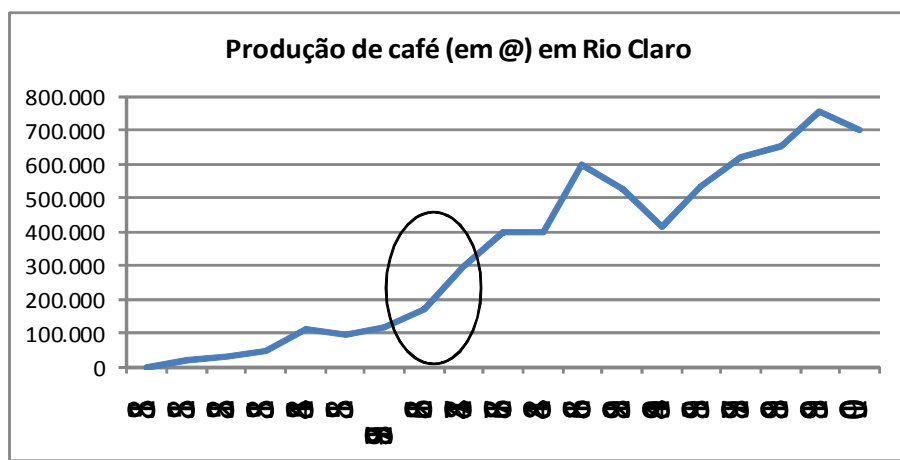

Dean, W. Op. Cit. p. 52

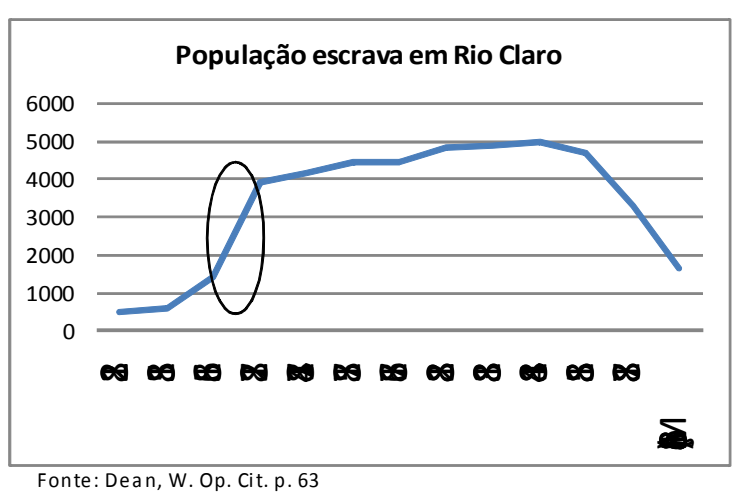

Por fim, o estudo de municípios é relevante, pois: estes são a unidade política básica do Brasil; no século XIX e início do XX, os municípios eram, em geral, bastante extensos ${ }^{34}$; os registros históricos referentes ao tráfico de escravos, ao regime de trabalho livre na lavoura e alusivos ao mercado de terras foram feitos por tabeliões e servidores públicos pertencentes aos quadros das burocracias municipais; no Arquivo do Estado de São Paulo, volumosa correspondência é classificada segundo o município e também, no Museu Paulista, o material avulso sobre Rio Claro está indexado pelo município. Portanto, além dos motivos já apontados, aqui elegemos mais um que convalida o estudo da cidade: por razões de ordem prática.

Além disso, a pesquisa de um ou alguns municípios possibilita um sentido de atilamentos e coloca em primeiro plano elementos que se dissolveriam com recortes mais amplos os quais, muitas vezes, apresentam o inconveniente de forçar o confronto de séries de dados decorrentes de médias gerais e, muitas vezes frouxas, que aplainam os acontecimentos e apegam-lhes os aspectos peculiares. Deste modo, ao contrário do que sugeriu Lucien Febvre certa feita, "números falsos, curva verdadeira"

\footnotetext{
34 Algumas informações importantes sobre o município de Rio Claro, encontram-se em: IBGE, Disponível em: http://www.ibge.gov.br/cidadesat/painel/painel.php?codmun=354390\#. Acesso em: 9/02/2012.
} 
aqui pretendemos, o máximo possível, 'números verdadeiros, curva verdadeira', o que em virtude do recorte espacial, temporal e dos dados por nós levantados é factível.

\section{Recorte temporal: 1861-1869}

Com relação ao recorte temporal, o período compreendido entre o fim do tráfico Atlântico e a abolição da escravatura contém importantes diferenças no que diz respeito ao comércio interprovincial e intraprovincial de escravos. Jacob Gorender, por exemplo, apresentou uma periodização dividindo-o em três fases: "nos anos cinquenta - intensa; nos anos sessenta - moderada; nos anos setenta - muito intensa"35.

Segundo o autor, a dinâmica deste tráfico nos anos 1850 se explica em virtude da grande prosperidade europeia que suscitou ampla demanda dos produtos de exportação dos países escravistas remanescentes (Brasil, Cuba e Estados Unidos).

Os anos sessenta foram distinguidos pela concomitância de dois movimentos contrários. A Guerra de Secessão nos Estados Unidos (1861-1865) abriu o mercado inglês ao algodão brasileiro, o que beneficiou os plantadores nordestinos - a produção de algodão, durante o decénio, mais do que duplicou em volume e o seu valor exportado aumentou mais do que cinco vezes. Ao mesmo tempo, a produção cafeeira do sudeste diminuiu o ritmo de crescimento, segundo o autor, em virtude da crise bancária de 1864 e por baixas recorrentes nas cotações internacionais do fruto da rubiácea. Frente a este cenário, os plantadores nordestinos desfrutaram de uma melhor correlação de forças para manter os cativos em suas regiões ${ }^{36}$.

Nos anos setenta, de um lado a expansão algodoeira esmoreceu e, de outro, a natureza por meio de diversas estiagens alongadas, forçaram muitos proprietários nordestinos a desfazerem-se dos seus escravos, o que estimulou o influxo de escravos do "norte" para o sul do país. Concomitantemente a esses acontecimentos, e a produção cafeeira prosseguiu, com maior vigor, a sua marcha leste-oeste, avanço perambulante que vez ou outra sofreu paralisias mais ou menos bruscas e criou, reiteradamente, cidades mortas nas quais os remanescentes "gabam a passada prosperidade, lamuriam do presente e pitam - pitam longos cigarros de palha, matadores do tempo" ${ }^{37}$. Aliado a esta dinâmica, a Lei do Ventre Livre (setembro de 1871) esfriou o movimento abolicionista e deu ao regime escravocrata renovada estabilidade política. Tal cenário fez com que o preço dos escravos homens com idade entre 20 e 25 anos, nos municípios cafeeiros, alcançasse mais de 2:000\$000 no final desta década, ponto mais alto do século $\mathrm{XIX}^{38}$.

\footnotetext{
${ }^{35}$ Gorender, J. Op. Cit. p. 326

${ }^{36}$ Segundo Furtado: A partir dos anos sessenta, a questão da oferta da mão-de-obra tornou-se particularmente seria. A melhora nos preços do café fazia mais e mais atrativa a expansão da cultura; por outro lado, a grande alta dos preços do algodão provocada pela Guerra de Secessão nos EUA dera início a uma grande expansão da cultura da fibra nos Estados do norte, restringindo-se em consequência o trafico de escravos para o sul. Furtado, Op. Cit. p. 126. Alguns dos aspectos que, de acordo com Gorender, justificam a ocorrência de um tráfico interno de escravos de intensidade moderada, nos anos 1860, foram corroborados por outros autores. Por exemplo, Richard Grahan afirmou que o número dos envolvidos no tráfico interno de escravos declinou um pouco nos anos 1860 "porque a Guerra Civil nos Estados Unidos encorajou a produção de algodão para compensar a escassez das exportações americanas para a Inglaterra, e os produtores do Nordeste por esta razão, uma vez mais, puseram alto preço nos seus escravos". O mesmo argumento foi usado por Maria José de Souza Andrade em A mão-de-obra escrava em Salvador, 1811-1860. Graham, R. Op. Cit. p. 129. O mesmo argumento foi usado por Maria José de Souza Andrade, A mão-de-obra escrava em Salvador, 18111860.São Paulo: Corrupio; Brasília: CNPq, 1988. p. 125; Andrade, Maria José de Souza. A mão de obra escrava em Salvador, 1811-1860. Corrupio, 1988.

${ }^{37}$ Lobato, M. A vida em Oblivion. Em Op. Cit. p. 26

${ }^{38}$ Gorender, J. p. 328 O mesmo argumento é usado por Graham, vejamos: “(...) o tráfico de escravos interprovincial se tornou muito mais intenso nos anos 1870, quando os preços internacionais do algodão e do açúcar declinaram precipitadamente enquanto que o do café disparou". Graham, R. Op. Cit. p. 126. Robert W. Slenes, por sua vez, estimou em 10 mil por ano o número de escravos comercializados nesta década, isto é, quase o dobro do nível anterior. Robert W. Slenes, "Grandeza ou decadência? O mercado de escravos e a economia cafeeira da província do Rio de Janeiro, 1850-1888", em Iraci del Nero da Costa (org.), Brasil: História econômica e demográfica (São Paulo, Instituto de Pesquisas Econômicas), 1986, pp. 110-33. Esta periodização é parcialmente corroborada por Neves, que estudou a dinâmica do comércio de escravos do alto sertão da Bahia para o oeste cafeeiro paulista. Este autor nos diz: "logo após o fim do tráfico externo, o número de cartas de liberdade de Caetité declinou 12,4\% comparativamente aos 10 anos anteriores, aumentando 13,3\% no período seguinte e novamente diminuindo 3,3\% no decênio de 1870, quando se intensificou o tráfico interno". Neves, Op. Cit. p. 105. Alguns números corroboram as afirmações que vimos, vejamos: Segundo João José Reis, a população escrava paulista passou de $80.000 \mathrm{em} 1864$ para $174.262 \mathrm{em} 1874,167.49 \mathrm{em} 1884$ e 107.392 em 1887, enquanto a do nordeste foi para estes mesmos anos de 774.000; 435.687; 301.470 e 171.797. Presença Negra: conflitos e encontros. In Brasil: 500 anos de povoamento. Rio de Janeiro: IBGE, 2000. P. 91. 38. Já de acordo com Joaquim Floriano de Godoy a população escrava de São Paulo cresceu de 80.000 em 1866 para 200.000 em 1875 . A província de São Paulo (Rio de Janeiro, 1875), p. 136, citado em Nicia Vilela Luz, "A administração provincial de São Paulo em face do movimento
} 
Não obstante estes comentários pontuais, nós não objetivamos realizar, neste trabalho, uma análise circunstanciada do comportamento/intensidade do tráfico interno de escravos nas décadas de 1850 e 1870, conforme a periodização proposta por Gorender. Não faremos isto, pois este artigo se deterá no exame dos dados que coletamos para o período compreendido entre 1861 e 1869, ou seja, para o período no qual o tráfico interno de cativos foi qualificado por Gorender como moderado.

Além de seguirmos a periodização proposta pelo autor de $O$ escravismo colonial, o nosso recorte temporal ainda justifica-se pela maior disponibilidade de Escrituras de compra e venda de escravos a partir de 1861. Esse maior número de registros, ao que parece, decorreu da vigência do decreto imperial que previa o lançamento das Escrituras de negócios com escravos de valor superior a duzentos mil-réis em livros de notas específicos para essa finalidade. Sobre esse registro, o Decreto $\mathrm{n}^{\circ}$ 2.699, de 28 de novembro de 1860, dispunha o seguinte: “Art. $3^{\circ}$ A Escritura pública é da substância de todo e qualquer contrato de compra e venda, troca e dação in solutum de escravos, cujo valor ou preço exceder de 200\$000, qualquer que for o lugar em que tais contratos se celebrarem ou efetuarem"39.

Tal assertiva é corroborada pelos termos de abertura dos livros cartoriais destinados a registrar a compra e venda de escravos. Em um dos livros que examinamos em Rio Claro - cronologicamente o primeiro livro pertencente ao acervo do Segundo Cartório de Notas e Protestos deste município -, lemos, em sua primeira página, o seguinte escrito: "Servirá este livro para o segundo tabelião Thomas Carlos de Mollina lançar as Escrituras de compra e venda de escravos em conformidade do decreto número 2.699 de 28 de novembro de 1860 , art. $3^{\circ}$, $\S 1^{\circ}$, o qual vai por mim numerado e rubricado".

No que diz respeito especificamente a Rio Claro, percebemos que a dinâmica geral apontada por Gorender para a década de 1860, e corroborada por outros autores - tráfico de intensidade moderada - é valida quando temos em vista o comércio interprovincial, sobretudo do nordeste para o sudeste. Quando lemos os dois últimos gráficos reproduzidos acima, acerca da produção cafeeira e da população escrava, apreendemos que houve durante a década de 1860 , de um lado, o mais intenso crescimento da população escrava, em Rio Claro, entre 1822-1888 e, de outro, forte correlação entre expansão dos cafeeiros e absorção de mão-de-obra escrava neste município. Os motivos, tal como apontaremos a frente, que explicam porque Rio Claro - acompanhando a dinâmica observada no restante do oeste histórico da província de São Paulo (ver o conjunto de gráficos da página 7) - teve possibilidade de aumentar largamente a sua população escrava em um contexto no qual o tráfico foi apenas moderado, reside na preponderância do comércio intraprovincial de cativos e das compras e vendas de escravos ocorridas entre Rio Claro e províncias próximas, nomeadamente Rio de Janeiro e Minas Gerais.

\section{Núcleo documental}

A pergunta que esteve presente quando buscávamos eleger o núcleo documental desta pesquisa foi: quais documentos podem fornecer o maior número de informações e, posteriormente, com o desenrolar de nossas investigações, nos permitir comparar a dinâmica do tráfico interno de cativos entre diferentes municípios?

Tendo esta pergunta em vista, percorremos parte da bibliografia que perpassa o nosso tema procurando referências que nos pudessem ajudar. Após concluirmos algumas leituras, o que de fato nos ajudou foi a percepção de que são escassos os trabalhos que examinaram, detidamente, um relevante núcleo documental existente e disponível ao público. Referimo-nos aos distintos arquivos cartoriais existentes nos diferentes municípios. A partir desta constatação, optamos pela compilação e análise dos diversos dados presentes em parte das Escrituras cartoriais, que conformam, por um lado os livros notas que registraram exclusivamente as compras e vendas de escravos, a partir de 1861, e, por outro, os livros de notas gerais ${ }^{40}$, preservados pelos Cartórios de Notas e Protestos (Primeiro e Segundo) do município que estamos investigando.

\footnotetext{
abolicionista", Revista de Administracao, VIII, 85.

${ }^{39}$ No $\S 1^{\circ}$ deste artigo lemos: "As Escrituras serão lavradas por ordem cronológica em livro especial de notas, aberto, numerado, rubricado e encerrado na forma da Legislação em vigor, por Tabelião de notas legitimamente constituído (...), e conterão (...) os nomes e moradas dos contraentes, o nome, sexo, cor, officio, ou profissão, estado, idade e naturalidade do escravo e quaisquer outras qualidades ou sinais que o possam distinguir”. Coleção de Leis do Império do Brasil, citado por Motta, J. F. Op. Cit. p. 63.

${ }^{40}$ Estes livros constituíam a única forma de registro público existente à época. Assim sendo, os encontramos, nos livros gerais, Escrituras dos mais variados tipos além das de compra e venda de escravos.
} 
As fontes notariais manuscritas que registraram a compra e venda de escravos contém precioso conjunto de informações sobre o tráfico interno destes. Dentre outros aspectos, encontramos aí: (i) a data da transação; (ii) os nomes do vendedor, do comprador e do escravo comerciado; (iii) as cidades de origem do vendedor e do comprador; (iv) a idade do escravo; (v) o número de escravos envolvidos; (vi) a cor do cativo; (vii) o preço da transação; (viii) o lugar de origem do escravo; (ix) o uso do escravo (lavoura, serviço doméstico, pedreiro etc.), (x) a identificação se o escravo era casado, solteiro, viúvo.

Sempre que disponíveis e legíveis, coletamos as informações constantes nas Escrituras mencionadas para o período 1861-1869. Finalmente, as características destes documentos oficiais lavrados no primeiro e segundo Cartório de Notas de Rio Claro cujos arquivos fizemos ampla varredura favoreceram, largamente, a abordagem quantitativa. Todavia, não nos furtamos de realizar acurada abordagem qualitativa das fontes compulsadas.

\section{Comércio interno de escravos: Rio Claro, 1861-1869.}

Para este trabalho, lemos, reunimos e organizamos as informações constantes nas 320 Escrituras de compra e venda ${ }^{41}$ de escravos que conseguimos localizar nos arquivos do $1^{\circ}$ e $2^{\circ}$ Cartórios de Notas de Rio Claro. Estas Escrituras perfazem um total de 575 cativos - homens, mulheres, crianças e velhos, de ambos os sexos, "de nação" (originários do continente africano) ou crioulos (nascidos nas Américas/Brasil), muitos oriundos de outras províncias etc. - vendidos-comprados ao longo dos anos abarcados pelo intervalo 1861-1869.

As informações que encontramos perpassam a totalidade dos anos do nosso recorte temporal. Ao longo destes anos, encontramos maior número de negócios em 1864, ano em que 108 escravos foram negociados e, menor em 1862, quando 28 escravos trocaram de proprietário ${ }^{42}$. Destes quase seiscentos cativos, mais de quatro quintos foram negociados em transações envolvendo mais de um escravo $^{43}$ - a média das vendas foi de $1,8^{44}$. No gráfico a seguir, dispusemos o número de escravos transacionados segundo o ano de registro da Escritura.

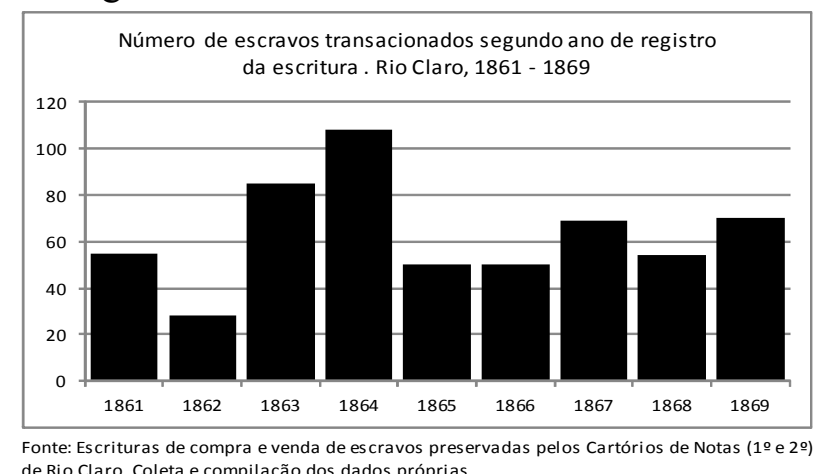

Vale salientarmos que mesmo possuindo certo padrão, diversas Escrituras apresentam algumas diferenças e particularidades o que, em parte, pode ser explicado pelos diferentes tabeliões e escreventes que elaboraram os registros ou por solicitação, de uma das partes envolvidas, de

\footnotetext{
${ }^{41}$ Além das Escrituras de compra e venda de escravos, encontramos certo número de documentos (relativamente ao conjunto documental levantado não muito expressivo) que registraram troca, doações, transferências e procurações. Todavia, estes processos não foram objeto de nossa análise.

${ }^{42}$ Mais uma vez, vale salientar que tais cifras registram o tráfico legal, submetido a taxas provinciais, omitindo o contrabando, reconhecidamente volumoso.

${ }^{43} 18$ Escrituras registraram a venda de 5 a 10 escravos, 7 consignaram negócios envolvendo mais de 10 escravos e várias outras vendas envolveram mais de um escravo. Os três negócios mais robustos envolveram a compra-venda de 31,17 e 16 escravos. A seguir, elencamos, brevemente, alguns dos dados que perpassam as duas primeiras transações mencionadas. A primeira foi realizada, em 07/06/1865, entre Anna Joaquina Nogueira de Oliveira e Antonio José Vieira Barbosa, ambos residentes em Rio Claro. Dos 31 cativos, 13 eram africanos e 18 crioulos, 16 eram homens, com idade média de 24 anos e 15 mulheres, com idade média de 30 anos. O preço médio de cada um destes escravos foi de 1:451\$612 reis. A segunda ocorreu em 16/07/1861. Como vendedor José Maria de Moraes e como comprador Francisco de Assis Barros, ambos residentes em Pirassununga. Dos 17 escravos, 7 eram homens, com idade média de 24 anos e 5 eram mulheres, com idade média de 23 anos. Além destes, haviam 5 meninos, com idade entre 1 e 6 anos. Todos filhos de algumas das escravas negociadas. Todos os 17 cativos foram registrados como crioulos.

${ }^{44}$ Número muito próximo do encontrado por W. Dean para o período 1861-1872, que foi de 1,7. Cf. Dean, W. op. cit. p. 67.
} 
assentamento de alguma especificidade relacionada ao acordo. Algumas vezes, tais particularidades acarretaram problemas para coletarmos os dados que pautam a presente análise.

Outros contratempos foram decorrentes da forma prosaica de registro das Escrituras. A dificuldade mais séria e recorrente foi originada pelas Escrituras que abarcam a compra-venda de mais de um escravo. Estas, normalmente, não especificam o preço de cada indivíduo, mas sim o preço do conjunto dos escravos negociados o que impossibilitou atribuirmos, de forma apropriada, o preço nominal dos escravos de acordo com a sua respectiva idade, habilidade etc. Portanto, na maioria das vezes, na média, os cativos das mais diferentes idades e qualificações apareçam com o mesmo preço. Deste modo, uma Escritura datada do "ano de nascimento do Nosso senhor Jesus Christo de mil oito centos e sessenta e dois, aos treze dias do mês de julho" registrou a venda de sete escravos perpetrada por Francisco José da Rosa ao Alferes José Augusto de Azevedo, este residente em Rio Claro, aquele morador de Sorocaba. Esta Escritura assim registrou o fato:

Francisco José da Rosa “(...) pela presente Escritura vende, como vendido tem, ao Alferes José Augusto de Azevedo sete escravos de que é senhor e possuidor, livre de qualquer onus, sendo Justino crioulo, de idade vinte tres anos, solteiro; Gregório crioulo de vinte e quatro, digo de vinte e tres annos, solteiro; Ricardo crioulo de trinta anos; Felizarda de idade de doze anos; Luiza crioula, de idade de trinta anos, Joanna crioula, de idade de sete anos e Claudio crioulo de idade de dezoito anos; cuja venda faz pela quantia de onze contos, quinhentos e cinquenta mil e ao comprador transfere todo o senhoril e domínio que tinha nestes escravos de ora avante (...). Declarou o vendedor que sendo o escravo Claudio doente de uma hepathite chronica, se obriga a fazer boa venda dele, isto é, se não se reestabelecer durante o prazo de um anno a contar desta data será obrigado a recebelo e restituir ao comprador a quantia de um conto e seiscentos mil reis, digo, um conto seiscentos e cinquenta mil reis, assim como se neste prazo morrer da dita enfermidade será obrigado a restituição referida quantia $(\ldots)^{45}$.

Ao lermos este exemplo, notamos que escravos com idades bastante distintas - quatro homens, dois com 23, um com 30 e outro com 18 anos e 3 mulheres, com 12, 30 e 7 anos - foram vendidos, conjuntamente, pelo preço de 11:650\$000, de tal modo que, em média, cada uma destas pessoas atingiu o preço de 1:650\$000. Mesmo o cativo Claudio que recebeu atenção especial no registro da venda por ser "doente de uma hepathite chronica" foi negociado por este mesmo preço.

Para atenuar este problema, quando, no decorrer deste trabalho fazemos apontamentos sobre o preço dos cativos, por um lado, indicamos o número de observações que levantamos, por outro, quando possível, trabalhamos com o preço presente em escrituras que envolveram a venda de apenas um indivíduo.

Todavia, a parte as Escrituras que possuíam traços distintivos ou alguma outra vicissitude, os negócios que, habitualmente, apresentaram menor número de obstáculos foram as vendas que envolveram apenas um indivíduo. Podemos ilustrar esta fatia do tráfico humano, mediante a venda realizada em vinte sete de janeiro de 1866, do escravo Sebastião - crioulo-fula de 36 anos, solteiro, "de serviço de roça", natural de MG. Participaram como vendedor e comprador respectivamente Isabel S. Cardoso, moradora de Constituição (Piracicaba) e Manuelino de Godoy Bueno, de Rio Claro. Este cativo foi vendido por intermédio da mercância intraprovincial por 1:050\$000, preço, diga-se de passagem, significativamente mais baixo ( $28 \%$ menor) do que a média dos escravos homens, com idade entre 31 e 45 anos negociados neste tipo de transação, como veremos mais a frente ${ }^{46}$.

Para além deste preâmbulo, iniciamos a nossa análise mediante a tabela e gráfico abaixo. Aí observamos, primeiramente e de passagem, a discrepância dos preços levantados por W. Dean em seu livro Rio Claro: um sistema brasileiro de grande lavoura e pela nossa pesquisa. Enquanto Dean, aferiu os preços que discute em "livros de vendas de escravos, livros de notas e inventários" ${ }^{47}$, nós nos baseamos nos livros de notas que registraram as compras e vendas de escravos, o que talvez coincida com o primeiro conjunto de documentos apontado por aquele autor. Em seguida, abordamos a dinâmica do preço nominal médio dos escravos e escravas negociados, em Rio Claro, ao longo do espaço de tempo que elegemos.

\footnotetext{
${ }^{45} \mathrm{O}$ documento relativo à negociação destes escravos encontra-se no arquivo do $1^{\circ}$ Cartório de Notas e Protestos de Rio Claro. Itálico nosso. Nós não realizamos a modernização dos trechos extraídos dos documentos que reproduzimos neste trabalho.

${ }^{46}$ A Escritura, registrando a venda do cativo Sebastião, é preservada pelo $2^{\circ}$ Cartório de Notas e Protestos de Rio Claro.

${ }^{47}$ Dean, W. Op. Cit. pág. 66.
} 
Preços mêdios, em mil-reis, de escravos masculinos, de 15 a 29 anos Rio

\begin{tabular}{c|c|c|c|c|c}
\hline \multirow{2}{*}{ Anos } & \multicolumn{6}{|c|}{ Rio Claro - W. Dean } & \multicolumn{2}{c|}{ Rio Claro - G. Rossini } & Confronto dos \\
\cline { 2 - 6 } & $\begin{array}{c}\text { Número de } \\
\text { dasos dos }\end{array}$ & $\begin{array}{c}\text { Preço } \\
\text { médio em } \\
\text { mil réis }\end{array}$ & $\begin{array}{c}\text { Número de } \\
\text { casos }\end{array}$ & $\begin{array}{c}\text { Preço médio } \\
\text { em mil réis }\end{array}$ & $\begin{array}{c}\text { decorrentes das } \\
\text { duas pesquis as }\end{array}$ \\
\hline 1862 & 10 & 1.860 & 12 & 1.685 & 9,4 \\
\hline 1863 & 8 & 1.920 & 35 & 1.683 & 12,3 \\
\hline 1864 & 4 & 1.970 & 29 & 1.694 & 14,0 \\
\hline 1865 & 1 & 2.000 & 15 & 1.750 & 12,5 \\
\hline 1866 & 4 & 1.500 & 15 & 1.621 & $-8,1$ \\
\hline 1867 & 3 & 1.700 & 37 & 1.613 & 5,1 \\
\hline 1868 & - & - & 22 & 1.557 & - \\
\hline 1869 & - & - & 41 & 1.709 & - \\
\hline
\end{tabular}

Fonte: Warren Dean, Rio Claro:..., p. 66 e Escrituras de compra e venda de escravos preservadas pelos Cartórios de Notas (1으 2으) de Rio Claro. Col eta e compilação dos dados próprias.

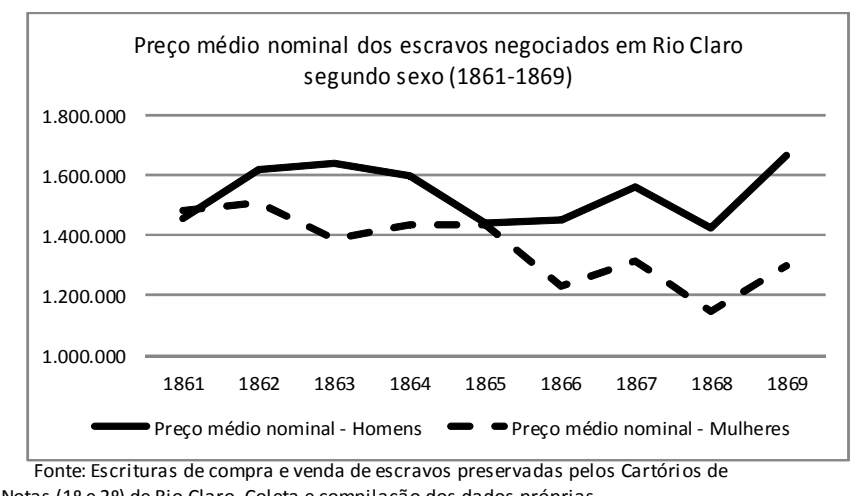

Notas (1ํ e 2) de Rio Claro. Coleta e compilação dos dados próprias.

Este gráfico nos permite apreender que a oscilação do preço médio nominal dos homens ocorreu majoritariamente dentro do intervalo $1: 400 \$ 000$ a 1:600\$000, enquanto a variação do preço das mulheres foi reiteradamente inferior. Fato que nos consente afirmar, tendo em vista a pouca diferença na esperança de vida entre os sexos, como afiança parte da literatura, que a distinção entre os preços de cativos e cativas era decorrente, sobretudo, da produtividade do trabalho. A recorrência de preços maiores para os escravos homens indica serem estes mais produtivos. Além disso, mesmo tendo em conta a limitação geográfica que perpassa esta série histórica, podemos relativizar proposições feitas por alguns autores ${ }^{48}$. Alguns têm sugerido que o preço das escravas em idade útil, grosso modo, entre os 15 e 40 anos, em virtude de distintos episódios que representaram ameaças a continuidade do comércio escravo, aumentaram intensamente em relação ao dos escravos, pois "se o tráfico de escravos tivesse terminado, a continuidade da escravidão só estaria garantida com a decisiva emulação do aumento natural que ocorria nos Estados Unidos (...) a ameaça ao comércio escravagista imposta pelas atividades dos ingleses era um lembrete evidente da importância decisiva das mulheres em idade de parir para o futuro da mão-de-obra escrava"49.

Bergad, por exemplo, quando escreveu sobre a dinâmica do preço dos escravos em algumas localidades mineiras, chama atenção para dois episódios que colocaram em primeiro plano o potencial reprodutivo das escravas, fazendo com que o preço destas se igualasse ao preço dos escravos homens. O primeiro foi um episódio efêmero que ocorreu em 1814, e talvez tenha antecipado o tratado de 1815 entre Inglaterra e Portugal, banindo o tráfico escravagista para o norte do Brasil e sinalizando prenúncio ruim para o futuro desse comércio. Segundo o mesmo autor, outro momento em que as mulheres em idade de trabalho tiveram o mesmo valor dos homens no século XIX foi em 1850, às vésperas da proibição definitiva do comércio escravagista transatlântico para o Brasil. Mais uma vez, temos, conforme as conjecturas de Bergad, um repentino aumento do preço das escravas resultante do seu potencial reprodutivo ${ }^{50}$. Por fim, vele notar que de acordo com os dados apresentados por este autor tal fenômeno não se repetiu nos anos que antecedem e mesmo coincidem com a promulgação, no início da década de 1830, da proibição - natimorta - do tráfico transatlântico de cativos.

Contudo, quando olhamos para os dados decorrentes de um importante centro produtor e demandante de força de trabalho do oeste paulista, como Rio Claro, descobrimos que existiram dois momentos, ao longo da década de 1860, nos quais o preço das mulheres coincidiu com o preço dos escravos homens, 1861 e 1865 . Coincidências essas que aparentemente não se justificam por situações adversas que atribuiriam maior importância ao potencial reprodutivo das escravas. Talvez, esta

\footnotetext{
${ }^{48}$ Para levarmos esta ponderação a frente é obviamente necessário ampliarmos o recorte geográfico.

${ }^{49}$ BERGAD, Laird W. Escravidão e história econômica: demografia de Minas Gerais, 1720-1888. EDUSC, 2004. P. 260.

${ }^{50}$ Cf. BERGAD, Laird W. Op. Cit. p. 246-253. Esta proposição é em parte corroborada por Stein, quando nos diz: “Até que o fim do tráfico de escravos forçasse os fazendeiros a cuidar mais das necessidades físicas de seus escravos a fim de prolongar a sua vida produtiva, eles procuravam trabalhadores para o campo que pudessem dar tudo de si de maneira eficiente e os substituíam par novas levas. Sob tais circunstâncias, os fazendeiros preferiam homens a mulheres, pois durante o final da gestação e os meses após o parto não se podia contar com o trabalho feminino nos campos e nas encostas de café. Consequentemente, entre os africanos em Vassouras, a proporção entre homens e mulheres era em torno de sete para três, e era sem dúvida o índice normal de nascimento que mantinha essa proporção entre a população escrava. No entanto houve uma mudança, de $77 \%$ de homens e $23 \%$ de mulheres na década de $1820-1829$ para $56 \%$ e $44 \%$ respectivamente em 1880-1888. A mudança foi tão gradativa que se pode concluir que a sociedade escrava de Vassouras permaneceu predominantemente masculina durante o crescimento e o declínio do município.” Op. Cit. p. 108.
} 
dinâmica dos preços em 1865, por exemplo, se explique em virtude da Guerra do Paraguai e da consequente Lei 1101 de 20 de setembro 1865 , que em seu art. $5^{\circ}$ parágrafo $4^{\circ}$, facultou a substituição do convocado ou recruta por outra pessoa, possivelmente um escravo. Acontecimento e promulgação que pode ter direcionado, ao longo dos esforços iniciais da guerra, maior volume de escravos homens para terras paraguaias, aumentando a demanda por escravas, o que pode ser justificado pelo significativo aumento da produção de café em Rio Claro (entre 1859 e 1862, houve um aumento de quase $70 \%$ e, entre 1862 e 1874 , a expansão foi próxima de $60 \%{ }^{51}$ ). Tais oscilações também podem residir na subida dos preços dos produtos de primeira necessidade na Europa e nos EUA, tal como ocorrera no final da década de 1850.

Para além destes dois momentos cujos preços dos escravos homens e mulheres coincidiram, prevaleceu, como observamos no gráfico, certa dinâmica adversa do preço das escravas, que transcorreu toda a década de 1860. Enquanto no início deste decênio as cativas foram vendidas por 1:484\$778, no final elas foram mercadejadas por 1:300\$000. Quiçá, tal comportamento justifica-se pelos desdobramentos do processo abolicionista geral, o qual vivenciou na década de 1860 momentos relevantes, quais sejam: (i) o fim da Guerra Civil norte americana teve como uma das suas consequências a abolição da escravidão; (ii) em 1867, o comércio escravagista cubano foi encerrado; (iii) extrapolando um pouco o nosso período, em 1871, a Lei do Ventre Livre "libertou" todos os filhos nascidos de mães escravas, medida que resultou em significativa mudança nos valores relativos dos escravos por sexo, o que talvez possa ser explicado, em parte, pela impossibilidade de continuar se levando em conta o potencial reprodutivo das escravas.

Também vale notarmos que os dados por nós compilados aproximam-se, até certo ponto, das longas séries organizadas e estudadas por Fogel e Engerman sobre o sul dos EUA e por Bergad sobre Minas Gerais. Estes autores descobriram que, em torno dos 27 anos de idade, o preço das escravas era cerca de $80 \%$ do preço dos escravos, diferencial próximo ao encontrado por nós em Rio Claro entre os escravos e escravas com idade entre 25 e 29 anos $(87 \%)^{52}$.

Além do confronto entre os preços dos cativos homens e mulheres, gostaríamos de frisar que quanto às crianças, levantamos os seguintes dados: crianças de 3-4 anos custavam aproximadamente 400.000 e com 10 anos $1.400 .000^{53}$, ou seja, $24 \%$ e $89 \%$ respectivamente do preço médio de um escravo com idade entre 15 e 29 anos (1.640.000), na década de 1860. Já com relação à cor, percebemos que o preço dos escravos não variava de forma significativa, tal como podemos apreender por meio da tabela abaixo (a exceção, não relevante por ser formada por apenas um indivíduo, é o preto-fula negociado por dois contos de réis).

\begin{tabular}{|c|c|c|}
\hline Cor & Número de escravos & Preço médio \\
\hline Preto(a) & 109 & 1.653 .879 \\
\hline Pardo(a) & 30 & 1.525 .611 \\
\hline Cabra & 22 & 1.674 .310 \\
\hline Mulato(a) & 16 & 1.643 .750 \\
\hline Fula & 9 & 1.643 .650 \\
\hline Mestiço & 1 & 1.692 .857 \\
\hline Preto-Fula & 1 & 2.000 .000 \\
\hline
\end{tabular}

Por sua vez, quando organizamos os dados para acessarmos informações relativas às famílias escravas ("estado civil" e filhos declarados) temos o resultado abaixo. Estes dados podem refletir a expectativa das promulgações que ocorreriam respectivamente em 1869 e 1871. A primeira, em seu segundo artigo, decretou que "em todas as vendas de escravos, ou sejam particulares ou judiciais, é proibido, sob pena de nulidade, separar o marido da mulher, o filho do pai ou mãe, salvo sendo os

\footnotetext{
${ }^{51}$ Dean, W. Op. Cit. 52

${ }^{52}$ Fogel, R.; ENGERMAN, S. Time on the cross: The economics of American negro slavery. NY: Little, Brown, 1974. P. 75. Bergad, Op. Cit. p. 266.

${ }^{53}$ Para chegarmos a estes números consultamos as 6 Escrituras que registraram a vendas de apenas um escravo com 10 anos de idade, entre 1861-1869. Realizamos o mesmo procedimento para levantarmos o preço das crianças de 3-4 anos. Para estas últimas encontramos apenas dois registros que envolveram a venda de um único escravo.
} 
filhos maiores de 15 anos". Já a segunda, diminui a idade mencionada para 12 anos (ver nota de rodapé número 75$)$.

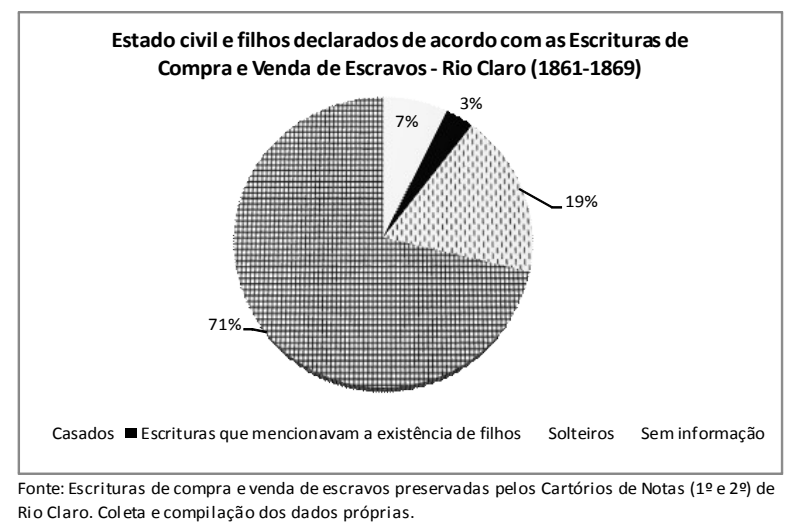

Nos gráficos seguintes, conjugamos duas informações relevantes: por um lado, dispusemos dados gerais acerca do percentual de indivíduos transacionados, em grupo ou individualmente e, por outro, agregamos a este levantamento as informações que obtivemos sobre o/a município/província de residência dos muitos que, assolados pela nostalgia da imoralidade, participaram do comércio de pessoas.

Contudo, antes de lermos estes gráficos cabe fazermos uma nota prévia. Este e outros arranjos dos dados que realizamos ao longo deste texto foram feitos de acordo com certa tipologia do comércio interno de seres humanos, que assim ficou estabelecida: houve o comércio local, que se caracterizou pelo fato de o vendedor e o comprador residirem na mesma cidade onde a Escritura de averbação do negócio foi elaborada e arquivada; existiu o tráfico intraprovincial, no qual o vendedor e/ou o comprador residiam em diferentes localidades da província de São Paulo; e, por fim, ocorreram as transações interprovinciais, nas quais as partes envolvidas moravam em distintas províncias do império ${ }^{54}$.

Dos 575 escravos negociados ao longo dos anos em apreço, identificamos a modalidade do tráfico para 412. Tendo estes números em vista, ao associarmos os registros comerciais que envolveram vendas individuais ou em grupo com a tipologia do tráfico interno de cativos, fica manifesta a preeminência do tráfico intraprovincial entre os escravos negociados em grupo $(47 \%)$ e do comércio local entre os cativos vendidos individualmente (55\%).

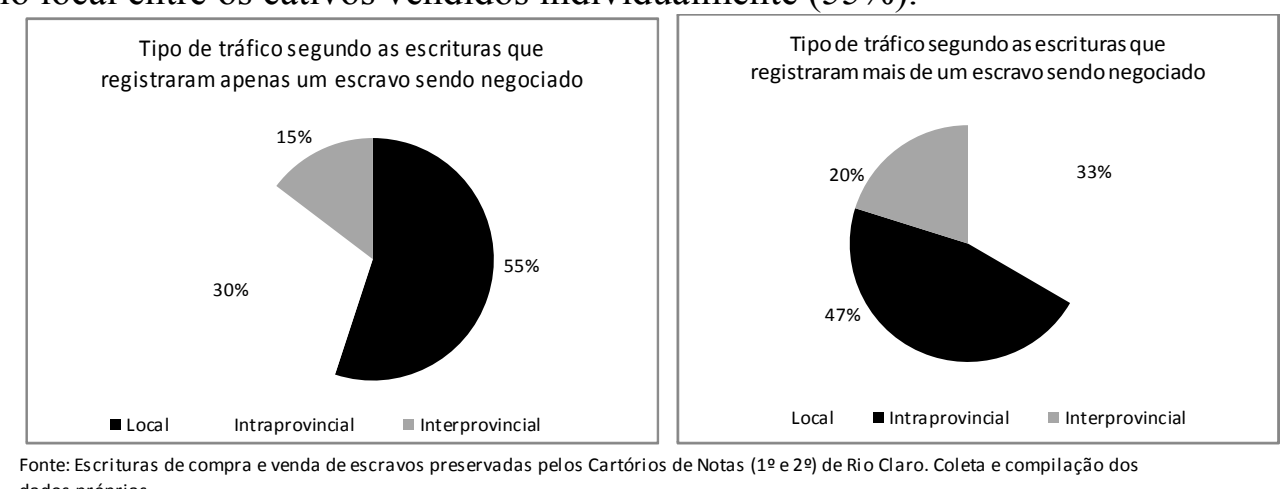

A classificação dos cativos negociados em Rio Claro de acordo com sexo, origem e tipo de tráfico foi organizada na tabela seguinte. Dos escravos para os quais identificamos o tipo de tráfico, $42,2 \%$ foram negociados por meio do tráfico intraprovincial, $31,1 \%$ por intermédio do comércio local e $18,7 \%$ foram adquiridos em outras províncias do império ${ }^{55}$. Com estes dados em vista, surge a pergunta: como explicar esse comércio local volumoso numa região cuja expansão econômica ocorreu,

\footnotetext{
${ }^{54}$ Esta tipologia não foi criada por nós. Alguns outros trabalhos que abordam a presente temática já a utilizaram. É importante frisarmos que, ao longo deste trabalho, reconhecemos certa ambiguidade na análise do tráfico local como distinto do intraprovincial. Para atenuar os contratempos daí decorrentes, tomamos o cuidado de, em nenhum momento, incorrermos em dupla contagem (agregarmos a movimentação do tráfico local com a do tráfico intraprovincial) para não distorcermos o volume do comércio intraprovincial.

${ }^{55}$ Desde já assumimos a influência dos trabalhos do professor José Flávio Motta sobre a análise quantitativa aqui realizada. Ademais, a proximidade que buscamos justifica-se por almejarmos confrontar os nossos resultados com as conjecturas decorrentes das pesquisas deste autor.
} 
majoritariamente, com o crescimento dos cafezais? Provavelmente: (i) parte destes cativos já se encontravam no município envolvidos com a cultura da cana, pois, por volta de 1825 haviam 11 engenhos na cidade e a produção de açúcar foi expressivamente ampliada até $1853^{56}$; (ii) parte já havia sido direcionado para o município em virtude dos momentos iniciais da expansão cafeeira pela região; (iii) parte destes escravos foram introduzidos na cidade por traficantes locais.

Respondida a pergunta anterior, vale ressaltar que mesmo tendo passado mais de uma década da extinção efetiva do tráfico transatlântico para o Brasil, os escravos "de nação" ainda perfaziam $10,2 \%$ do conjunto dos escravos cujo tráfico alcançamos aferir. Deste contingente, a grande maioria $(60 \%)$, foi comerciada no âmbito local, $35 \%$ migraram de um para outro município da província paulista e o restante passou de uma província para outra.

No campo dos negócios locais, estes africanos representaram $15,5 \%$ das 161 pessoas que aí trocaram de mãos. Dos 42 africanos vendidos por meio das três modalidades de tráfico, 28 eram homens, o que acarreta uma razão de sexo de 2 homens para cada mulher.

Dentre os escravos "de nação", observamos a maior disparidade entre os sexos na esfera do comércio intraprovincial, aí a razão de sexo é bastante elevada $(4: 1)^{57}$.

Os cativos africanos foram, predominantemente, negociados no interior de grupos mistos (africanos e crioulos), que abarcavam mais de 3 pessoas. Dos africanos vendidos durante os anos sessenta, apenas 6 foram negociados individualmente. Um, desses seis, foi o cativo Manoel, de 32 anos, quiçá novamente teve de deixar para trás família, amigos, flertes e amores d'outrora. Manoel foi vendido, em dez de novembro de 1861, por Joaquim Teixeira das Neves, importante traficante de Rio Claro, a Antonio Rodrigues de Barros, habitante de Constituição (Piracicaba) por 1:500\$000 ${ }^{58}$. Além destes aspectos, o conjunto de Escrituras contendo transações com escravos originários de diferentes partes da África evidencia que 21 destes tinham idades igual ou inferiores a 30 anos, o que indica, por um lado, que foram traficados para o Brasil à revelia da proibição deste comércio, promulgada em 1831 e, por outro, a importância para o erário do império desta atividade, que de acordo com os dados levantados parece pontual mas, na verdade, era generalizada. Tal como nos diz Stein, "no meio da década de 1830, as finanças do Império estavam apoiadas na prosperidade dos cafeicultores, uma dependência mais forte do que a pressão da diplomacia inglesa aplicada durante 20 anos"

\begin{tabular}{|c|c|c|c|c|c|}
\hline Tráfico & Sexo & De nação* & Crioulos $* *$ & \begin{tabular}{|c|}
$\begin{array}{c}\text { Sem identificação } \\
\text { de origem }\end{array}$ \\
\end{tabular} & Total \\
\hline \multirow{4}{*}{ త్ } & Homens & 15 & 73 & 13 & 101 \\
\hline & Mulheres & 10 & 40 & 10 & 60 \\
\hline & Razão de sexo*** & 150,0 & 182,5 & 130,0 & 168,3 \\
\hline & Total $(\mathrm{H}+\mathrm{M})$ & 25 & 113 & 23 & 161 \\
\hline \multirow{4}{*}{ 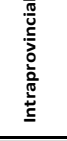 } & Homens & 12 & 95 & 15 & 122 \\
\hline & Mulheres & 3 & 42 & 7 & 52 \\
\hline & Razão de sexo & 400,0 & 226,2 & 214,3 & 234,6 \\
\hline & Total $(\mathrm{H}+\mathrm{M})$ & 15 & 137 & 22 & 174 \\
\hline \multirow{4}{*}{ 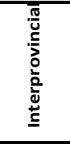 } & Homens & 1 & 58 & 8 & 67 \\
\hline & Mulheres & 1 & 8 & 1 & 10 \\
\hline & Razão de sexo & 100,0 & 725,0 & 800,0 & 670,0 \\
\hline & Total $(\mathrm{H}+\mathrm{M})$ & 2 & 66 & 9 & 77 \\
\hline
\end{tabular}

\footnotetext{
${ }^{56}$ Produção de açúcar (em @) em Rio Claro: $1822=10.533 ; 1835=11.800 ; 1853=34.800 ; 1862=17.600$. Dean, W. Op. Cit. p. 41.

${ }^{57}$ Vale enfatizarmos que esta razão de sexo é prejudicada pelo abreviado número de casos observados.

${ }^{58}$ Outro exemplo, é a escrava Emília de 35 anos, transacionada, em medos de 1868, por 1:300\$000. A Escritura registrando a venda de Manoel encontra-se no arquivo do $1^{\circ}$ Cartório de Notas e Protestos de Rio Claro, já o documento relativo à negociação da escrava Emília está preservado pelo $2^{\circ}$ Cartório de Notas e Protestos desse município.

${ }^{59}$ Stein, S. op. Cit. p. 93. Segundo o mesmo autor, o traficados à revelia da proibição ocorria da seguinte forma: "Em pontos estratégicos ao longo da costa, frequentemente nas proximidades do Rio, eram realizados desembarques de escravos contrabandeados. Mesmo quando apreendidos no ato, os juízes locais absolviam rapidamente os grupos envolvidos. Alguns fazendeiros e comerciantes tinham seus depósitos de africanos em locais costeiros isolados; nos barracões, os escravos eram supridos de roupa e alimento antes de serem embarcados em carros de boi para o interior. Uma vez que a incapacidade de falar português era a única prova da chegada recente - e uma prova duvidosa o comércio interno de escravos podia ser constante e ilicitamente abastecido com novas levas". Idem. P. 93
} 
Já os crioulos totalizavam $76,7 \%$ dos 412 escravos presentes na tabela anterior. $35,8 \%$, e $20,9 \%$, dos escravos desse grupo, foram vendidos-comprados por mediação do tráfico local e interprovincial, respectivamente. O contingente mais representativo, 43,4\%, foi objeto do comércio intraprovincial. No contexto desse comércio, os crioulos representaram 78,7\%. Agora, se excluirmos do tráfico intraprovincial os escravos cuja origem não foi relatada ao longo das Escrituras que registraram as vendas e compras dos cativos negociados em Rio Claro, este conjunto atinge mais de 90\% das pessoas vendidas no interior da província de São Paulo. Quando fazemos essa mesma ponderação (computar unicamente os cativos que tiveram a sua origem registrada), a proporção dos crioulos sobe para $81,9 \%$ no tráfico local e $97 \%$ vindos de outras províncias para algum município de São Paulo.

Para os crioulos, novamente encontramos razões de sexo elevadas para todos os tipos de tráfico. Registramos a diferença mais notável no comércio interprovincial, no qual esta relação atinge 7,25:1. No que diz respeito a esse último tipo de tráfico, temos, dentre vários outros, o exemplo da Escritura que registrou a venda de três escravos, em dezoito de abril de 1866. Os escravos negociados foram Paulino, Adão e Tolentino, respectivamente de 22, 20 e 16 anos de idade, todos crioulos, pretos roceiros e solteiros. Estes três homens foram transferidos da província do Rio de Janeiro para a cidade de Rio Claro com todas as suas chulices, calundus e quizílias, mediante o pagamento total de 5:100\$000, o que correspondeu a um preço individual médio de 1:700\$000.

$\mathrm{Na}$ tabela abaixo, dispomos os escravos que entraram ou saíram apenas do município de Rio Claro de acordo com sexo e modalidade do tráfico. Estas 201 pessoas correspondem a pouco mais de um terço (35\%) do conjunto de escravos negociados ao longo dos anos compreendidos entre $1861 \mathrm{e}$ 1869. Com o panorama formado por estes dados, mais uma vez, notamos: (i) largo predomínio dos indivíduos de sexo masculino em ambos os movimentos e; (ii) que o comércio intraprovincial abarcou um número significativamente maior de cativos $-71 \%$ do total.

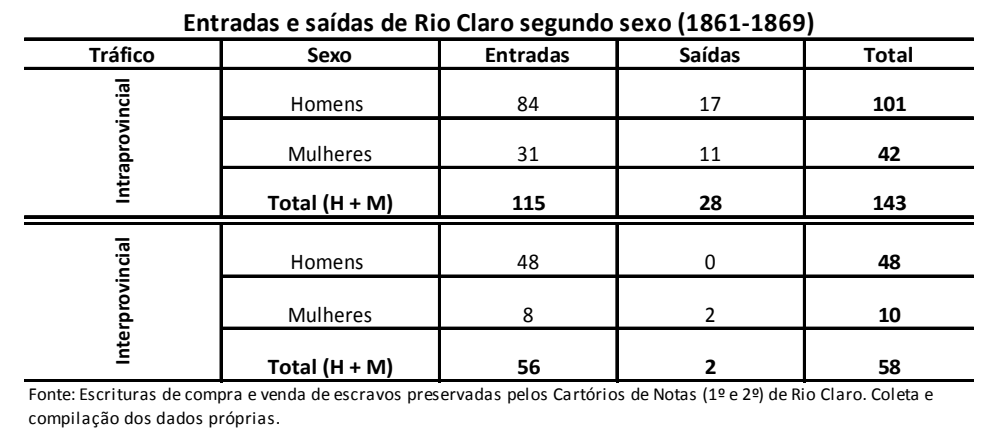

Também observamos vasta preponderância das entradas em relação às saídas tanto no que diz respeito ao movimento no interior do território paulista quanto entre diferentes províncias e Rio Claro. O que possibilita afirmarmos que, durante a década de 1860, este município não foi "uma espécie de pequeno entreposto deste tipo de transação", tal como afirmou W. Dean sobre a dinâmica deste comércio nesse município durante o período $1874-1885^{60}$. Com relação ao movimento interprovincial, a migração originária da província do Rio de Janeiro com destino a municipalidade em apreço foi a mais expressiva, aí registramos a "descida" de 73,2\% dos indivíduos comprados por escravagistas dessa cidade. Em seguida, temos Bahia, Minas Gerais e Santa Catarina. Enquanto essas duas últimas províncias forneceram pouco mais de $5 \%$ cada, a primeira contribuiu com $10,7 \%$.

Com respeito às entradas decorrentes do tráfico intraprovincial no município analisado, elaboramos a tabela a seguir ${ }^{61}$. Nela apreendemos que Santos e a cidade de São Paulo foram os principais provedores de braços escravos para Rio Claro. Estes municípios forneceram juntos $42,6 \%$ dos cativos que lá passaram a residir e sofrer o vaticínio dolente do cativeiro. A preponderância destas cidades pode ser explicada pelo fato de ambos serem entrepostos de escravos de outros municípios da província paulista e, sobretudo, Santos de outras províncias do império.

\footnotetext{
${ }^{60}$ Cf. Dean, W. Op. Cit. P. 69.

${ }^{61}$ As distâncias elencadas nesta tabela foram obtidas por meio do google-mapas. Portanto, elas não são decorrentes de linhas retas, mas sim da distância que um viajante hodierno enfrentaria por meio das principais estradas paulistas.
} 


\begin{tabular}{|c|c|c|c|c|c|}
\hline Município & $\begin{array}{l}\text { N. de escravos } \\
\text { que forneceu à } \\
\text { Rio Claro } \\
\end{array}$ & $\begin{array}{l}\text { Distância de Rio } \\
\text { Claro (em Km) }\end{array}$ & Município & $\begin{array}{c}\begin{array}{c}\text { N. de escravos que } \\
\text { forneceu à Rio } \\
\text { Claro }\end{array} \\
\end{array}$ & $\begin{array}{l}\text { Distância de Rio } \\
\text { Claro }(\mathrm{em} \mathrm{Km})\end{array}$ \\
\hline Santos & 28 & 252 & Campinas & \begin{tabular}{|l|}
2 \\
\end{tabular} & 83,8 \\
\hline São Paulo & 21 & 178 & Jacareí & 2 & 223 \\
\hline Sorocaba & 9 & 164 & Limeira & 2 & 31,5 \\
\hline Iguape & 8 & 355 & São Carlos do Pinhal & 2 & 60,8 \\
\hline Pirassununga & 8 & 82 & Botucatu & 1 & 147 \\
\hline Constituição & 7 & 39 & Franca & 1 & 268 \\
\hline Província de SP* & 5 & - & Itu & 1 & 123 \\
\hline Ubatuba & 5 & 394 & Pindamonhangaba & 1 & 328 \\
\hline Brotas & 4 & 74,3 & São Simão & 1 & 150 \\
\hline Jaú & 4 & 126 & Tiete & 1 & 85 \\
\hline Araraquara & 2 & 101 & - & - & - \\
\hline
\end{tabular}

Quando analisamos os documentos registrados em Rio Claro acerca do tráfico interprovincial com destino a São Paulo, nós nos deparamos com o resultado expresso no gráfíco abaixo. Aí, notamos a proeminência das províncias do Rio Janeiro e Minas Gerais no aprovisionamento de cativos que corroboraram a expansão dos cafeeiros na região da Baixa Paulista. Neste momento, vale a pena frisar os possíveis ganhos de arbitragem que os traficantes auferiam ao transferir escravos de Minas para Rio Claro. De acordo com os dados compilados por Bergad, em 1861, o preço médio dos escravos saudáveis dos dois sexos entre 15 e 40 anos de idade, em MG, era de 1:470\$000 e, em 1866, havia caído para $932 \$ 000^{62}$. Estes mesmos escravos em Rio Claro, no primeiro ano mencionado, eram vendidos, em média, por 1:610\$220 e, no segundo, por 1:460\$000; portanto, uma diferença de quase $10 \%$ em 1861 e de $56 \%$ em 1866 .

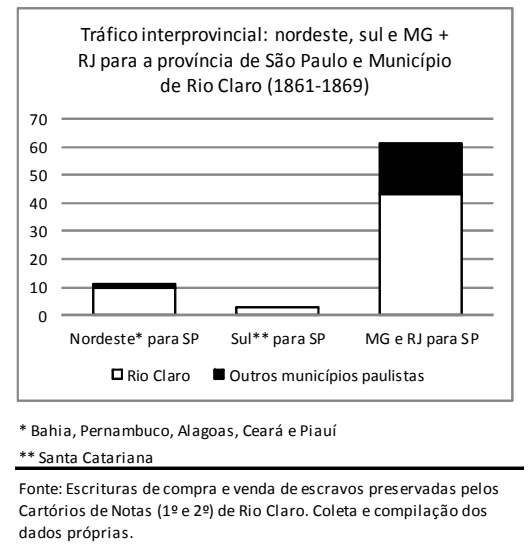

A seguir, conjugamos os dados que obtivemos relativos a idade, sexo, origem e preço nominal médio. Com estes dados em vista, fica claro que, para além do sexo, como já comentamos acima, a idade era o fator mais decisivo na valorização dos escravos. Além disso, quando comparamos os dois próximos gráficos, chama atenção: (i) que os dados confirmam a esperada desigualdade na distribuição etária de acordo com a origem dos escravos e (ii) o fato de não haver escravos "de nação" com idade inferior a quinze anos.
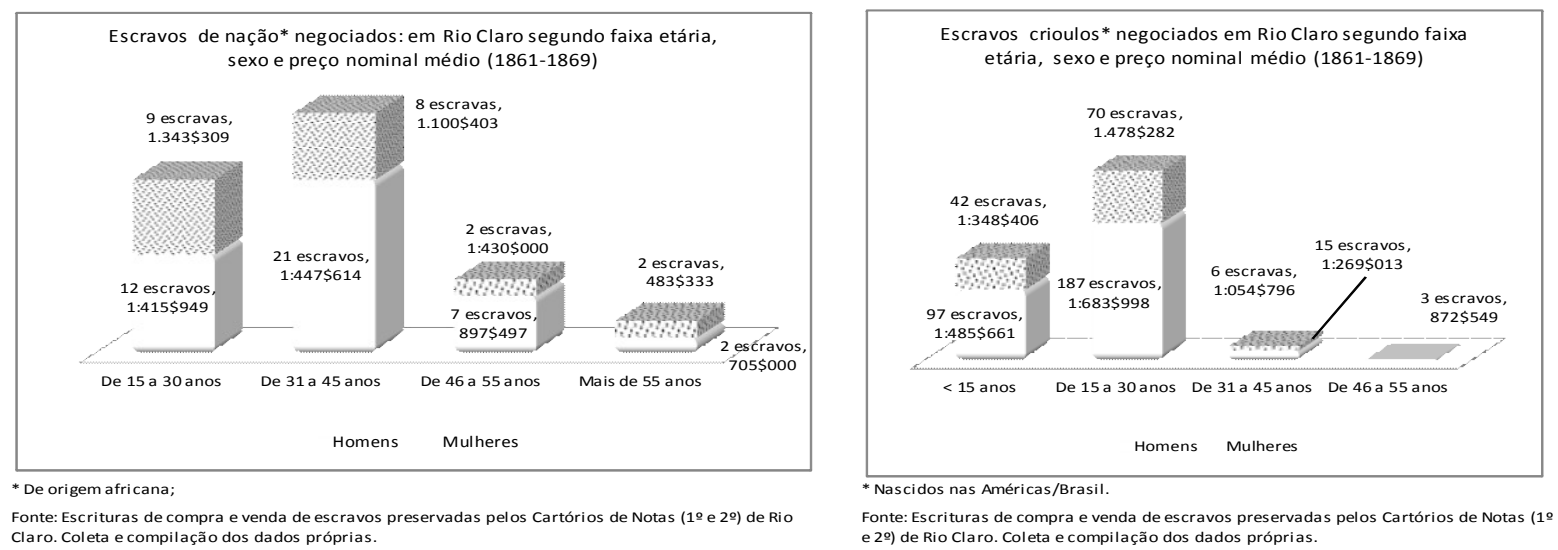

Ademais, quando agrupamos os escravos africanos com idade de até 45 anos, percebemos que $58 \%$ desses estão no intervalo etário de 31 a 45 anos - conjunto no qual os homens correspondiam a

\footnotetext{
${ }^{62}$ Bergad, L. W. Op. Cit. p. 256.
} 
$72,4 \%$. Em contrapartida, quando consideramos os dados concernentes aos cativos crioulos, notamos que, como lágrimas não eram argumentos, expressivo número de crianças e jovens $(33,3 \%$ com idade inferior a 15 anos) foi separado de suas famílias e vendido a outros proprietários ${ }^{63}$. Quantos destes se tornaram Prudêncios, cavalos de todos os dias que com as mãos no chão receberam "um cordel nos queixos, à guisa de freio", para terem os dorsos trepados e serem fustigados pela varinha de um molecote filho de seu proprietário, tal como Prudêncio de Machado ${ }^{64} .$. não sabemos.

Já os crioulos com idade inferior a 46 anos, apenas 5\% encontram-se na faixa etária de 31 a 45 anos, enquanto $61,6 \%$ possuíam entre 15 e 30 anos (desses $73 \%$ eram homens, o que origina uma razão de sexo de 267,0). Assim sendo, a maioria era de homens e estava em pleno vigor físico, adequada, deste modo, para o pesado trabalho na roça do café, verdadeiro castigo ${ }^{65}$.

Os dados anteriores corroboram parte da literatura que analisa o preço dos escravos em virtude da sua origem. Os dados que levantamos apoiam as hipóteses que asseveram que na maioria das sociedades escravistas onde ocorria o tráfico de escravos os crioulos dos dois sexos, em idade de trabalho, possuíam preços superiores ao dos africanos nas mesmas frações etárias. Quando cotejamos os preços nominais médios dos dois conjuntos de indivíduos, encontramos a diferença mais significativa entre os homens de 15 a 30 anos. Aí, ao passo que os cativos crioulos foram vendidos, ao longo da década de 1860, em média, por 1:683\$998, os africanos foram negociados por 1:447\$614, ou seja, uma desigualdade de pouco mais de $14 \%$, que, em parte, é explicada pelos africanos serem relativamente mais avelhantados, isto é, encontrarem-se, majoritariamente, mais próximo ao limite superior deste intervalo etário. Além destes aspectos, alguns elementos que talvez tenham influenciado a estrutura de preços dos escravos por ascendência são as seguintes: (i) Sobretudo os crioulos trabalhavam como empregados domésticos, carpinteiro, ferreiro, alfaiate, cocheiros ou em outros misteres mais estimados, ao posso que os africanos eram considerados, mais amiúde, lavradores sem outras habilidades. Para os dados que coligimos identificamos a ocupação de 32 escravos para além dos que estavam envolvidos no fadário da roça. Destes, apenas um era africano ou tal como usamos no presente texto, "de nação". Trata-se do escravo Antonio, preto, ferreiro, de 38 anos de idade, vendido por José C. Bastos para Ignácio Xavier Negreiros, por meio do tráfico intraprovincial, em dezembro de $1869^{66}$; (ii) Os compradores de escravos comumente confiavam que os escravos crioulos teriam vidas produtivas mais longas ${ }^{67}$; (iii) os escravos crioulos estavam com as doenças por aqui corriqueiras; (iv) Para as escravas, as taxas de fertilidade relativas a origem era outra importante variável de determinação do preço. Usualmente pressupunha-se que as crioulas eram mais férteis que as africanas, assim elas alcançavam preços mais altos ${ }^{68}$.

Além do mais, ao considerarmos a variável gênero, encontramos disparidades consideráveis, referentes ao preço nominal médio, no interior de cada grupo. Assim sendo, por exemplo, os homens africanos com idade entre 31 e 45 eram negociados por um preço $24 \%$ superior ao das mulheres. Já os

\footnotetext{
${ }^{63}$ A legislação com vistas a coibir a separação entre cônjuges e entre pais e filhos cativos entrou em vigência e abarcou apenas os últimos meses do período por nos estudado. Assim sendo, lemos no Decreto n. ${ }^{\circ} 1.695$, de 15 de setembro de 1869 , em seu artigo 2. ${ }^{\circ}$ " "em todas as vendas de escravos, ou sejam particulares ou judiciais, é proibido, sob pena de nulidade, separar o marido da mulher, o filho do pai ou mãe, salvo sendo os filhos maiores de 15 anos". (Coleção de Leis do Império do Brasil,1808-1889. Atos do Poder Legislativo de 1869. Disponível em: <http://www2.camara.gov.br/legislacao/publicacoes/doimperio>). Já a Lei Rio Branco (n. 2.040, de 28 de setembro de 1871), dispunha em seu artigo $4 .^{\circ}, \S 7 .^{\circ}$ uma nova idade para as separações entre pais e filhos, vejamos: "Em qualquer caso de alienação ou transmissão de escravos é proibido, sob pena de nulidade, separar os cônjuges, e os filhos menores de 12 anos, do pai ou mãe." (Coleção de Leis do Império do Brasil, 1808-1889. Disponível em: $<\mathrm{http} / /$ www2.camara.gov.br/legislacao/publicacoes/doimperio $>$.

${ }^{64}$ Prudêncio, personagem de Machado de Assis, era "fustigado pelo seu dono até dar "mil voltas a um e outro lado, e ele obedecia, - algumas vezes gemendo, - mas obedecia sem dizer palavra, ou, quando muito, um - 'ai, nhonhô' - ao que eu retorquia: - 'Cala a boca, besta!"'. Assis, Machado. Memórias Póstumas de Brás Cubas.

${ }^{65}$ Segundo Calmon, "veio a decadência dos engenhos. Na senzala, o negro vivia a sua vida: às vezes, alforriava-se. Os outros, do canavial e do fabricação do açúcar, tinham um dia seu, por semana; moravam em família: ouviam missa, na capela, junto da casa grande... A fazenda do café - sem essa aproximação de cativo e senhor — parecia um castigo: principalmente a fazenda nova. Nos engenhos patriarcais, suavizaram-se os contrastes". Op. Cit. p. 82. Um dado que em parte confirma esta proposição aparece em Neves, afirma que há 686 cartas de liberdade no Arquivo Público da Bahia para o período 1840 e 1879. Cf. Neves, E. F. Sampauleiros traficantes: comércio de escravos do alto sertão da Bahia para o oeste cafeeiro paulista. Afro-Asia, 2000, 97-128. p. 98.

${ }^{66}$ Escrituras preservadas pelo $2^{\circ}$ cartório de Notas de Rio Claro, em ordem cronológica, primeiro livro dedicado aos negócios com escravos neste município. Pág. 101 verso.

${ }^{67}$ Bergad, Op. Cit. pág. 271

${ }^{68}$ Idem. p. 271
} 
crioulos de 15 a 30 anos possuíam preço $12,2 \%$ maior do que o das mulheres ${ }^{69}$.

Em seguida, associamos a caracterização do tráfico, com a idade, o sexo e o preço médio nominal dos cativos. Ao fazermos isso, além de percebemos - como já evidenciado - que o comércio intraprovincial foi ligeiramente superior ao local e que o interprovincial ficou aquem de ambos, notamos, reiteradamente, no conjunto (homens e mulheres, de todas as idades e origens), alguns aspectos marcantes. Primeiramente, em todos os tipos de tráfico há significativa disparidade entre o número de homens e mulheres. Deste modo, enquanto a razão de sexo, para a comercialização local era de 1,7:1 e para o intraprovincial $3,75: 1$, para o interprovincial atinge a marca de, nada menos nada mais, 6,7:1. Aferimos ainda, que em todas as modalidades do comércio escravo prevaleceram transaçações envolvendo cativos jovens, com idade entre 15 e 30 anos. Esses sempre estiveram próximos dos $60 \%$ do total negociado em cada tipo de tráfico ${ }^{70}$.

Outro aspecto essencial novamente surge quando confrontamos preço e gênero. A dessemelhança é notória. Por exemplo, se centrarmos atenção na fatia etária que engloba a maior parte dos indivíduos vendidos mediante as três formas de tráfico, quer dizer, sujeitos com idade entre 15 e 30 anos, temos o seguinte resultado: no comércio local, enquanto os homens eram vendidos, em média, por 1:611\$068 as mulheres foram transacionadas por 1:489\$221. Já no tráfico intraprovincial os homens foram vendidos com um preço $15,6 \%$ superior ao das mulheres e no interprovincial os primeiros alcançaram um preço $12,5 \%$ maior.

Outrossim, apreendemos também que tanto os homens quanto as mulheres que sofreram as agruras do tráfico humano interprovincial possuiam preços superiores ao dos escravos e escravas que foram alienados por intermédio dos outros dois caminhos. Observamos esta mesma desigualdade nos demais parcelamentos estários que realizamos, com exceção: (i) da escrava Beralda, crioula, solteira de 45 anos, que passou pelo fado da

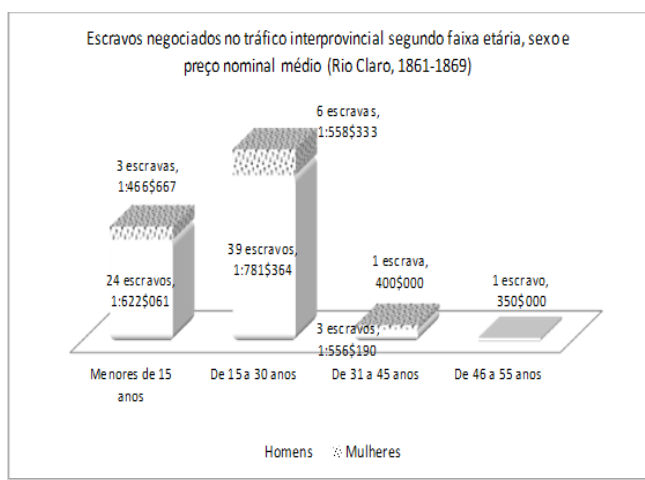

Fonte: Escrituras de compra evenda de escravos preservadas pelo $1^{0} \mathrm{e} 2^{\circ}$ Cartório de Notas de Rio Claro. Coletae compilação dos dados próprias.

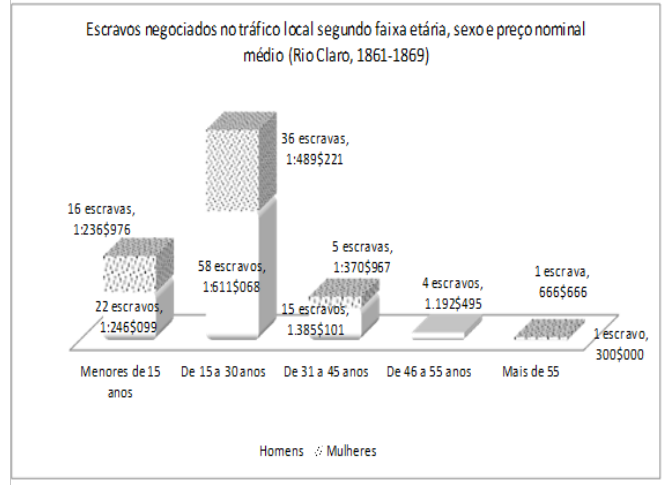

Fonte: Escrituras de comprae venda de escravos preservadas pelo $1^{2} \mathrm{e} 2^{2} \mathrm{Cartório} \mathrm{de} \mathrm{Notas} \mathrm{de} \mathrm{Rio} \mathrm{Claro.}$ Coletae compilação dos dados próprias.

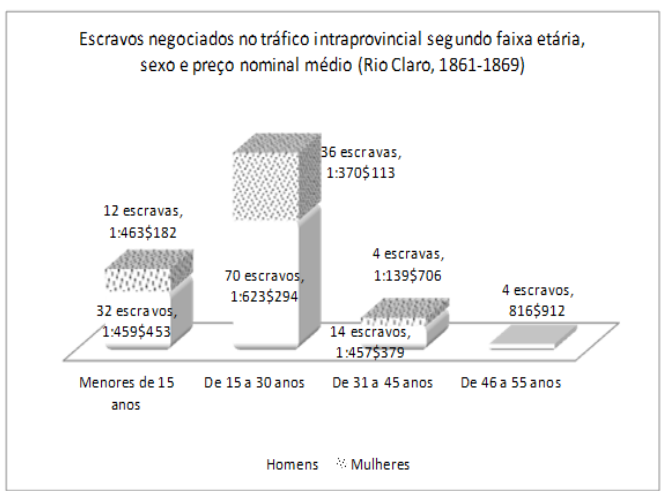

Fonte: Escrituras de compra e venda de escravos preservadas pelo $1^{\circ} \mathrm{e} 2^{\circ}$ Cartório de Notas de Rio Claro. Coleta e compilação dos dados próprias. barganha interprovincial (vendida por D. Josepha Maria da Conceição da cidade de São João Baptista, província de Santa Catarina e comprada por Francisco Villares Pinto da Palha, morador da cidade de Rio Claro por 400\$000). Além de Beralda encontrar-se no limite superior deste recorte etário, na Escritura que registrou os detalhes de como o "domínio e o senhoril" desta jovem senhora escrava passou de D. Josepha para Francisco Palha, lemos uma passagem que, talvez, nos ajude a esclarecer este preço de venda anormalmente baixo ${ }^{71}$, vejamos: o documento nos diz que a primeira vende ao

\footnotetext{
69 Vale observar que essa disparidade entre os valores de mercado dos escravos de acordo com o sexo seria posteriormente referendada pela legislação. De fato, na matrícula dos cativos brasileiros determinada pela Lei no 3.270, de 28 de setembro de 1885 , e regulamentada pelo Decreto no 9.517 , de 14 de novembro de 1885 , estabeleceu-se que "o valor seria declarado pelo proprietário do escravo, não excedendo o prego máximo regulado pela idade do matriculado, conforme tabela que consta do artigo $1^{\circ}$ da Lei [...] Sendo que o valor dos escravos do sexo feminino teria um abatimento de $25 \%$ sobre os pregos estabelecidos." Graf, 1974, p. 20, em Motta, J. F. Op. Cit, p. 101.

${ }^{70} 59,4 \%$ para o tráfico local, $61,6 \%$ para o intraprovincial e 58,4 para o interprovincial.

${ }^{71}$ A média do preço das escravas de 30 a 45 anos, vendidas no comércio local e intraprovincial foi de 1:370\$967 e 1:139\$706, concomitantemente.
} 
segundo a dita escrava, com "todos os seus achaques novos e velhos, vícios e defeitos ", quem sabe esses achaques, vícios e defeitos fossem manifestos e copiosos;

(ii) do escravo Caetano, preto de 50 anos, portanto, pertencente a penúltima fração etária por nós retalhada, que 'desceu a cambindar e saruê' - talvez com os urubus no seu encalço dizendo, lá de longe: "la vai o nosso comêt $\hat{7}^{72}$ - da província do Rio de Janeiro para o município de Rio Claro. Para tanto, Antonio J. Alves Fonseca recebeu de Francisco R. de Almeida a importância de 350\$000, ao passo que os homens dessa faixa etária ao longo dos documentos por nós compulsados, eram vendidos, em média, no tráfico intraprovincial por $816 \$ 912$ e no local por 1:192\$495.

Por fim, cabe fazermos alguns apontamentos acerca de outro aspecto de grande acuidade no âmbito de nossa análise, qual seja: a relação ocupação/experiência-preço. Dos escravos envolvidos nas diversas transações que perpassam a apreciação aqui empreendida, obtivemos o informe da ocupação de 98 indivíduos. A maioria absoluta - 67 pessoas - era de escravos dedicados ao eito das fazendas, ao trato da terra grosseira e crassa que exigia braços que ainda gozavam de pleno vigor, o que se traduz em homens de pouca idade. Como observamos na tabela, das 67 pessoas destinadas à roça, 59 eram homens e a idade média destes era 21,4 anos. A segunda ocupação mais recorrente foi a de serviços domésticos. Aí, mais uma vez, os homens foram maioria. Os demais cativos distribuíram-se pelas ocupações listadas abaixo ${ }^{73}$.

\begin{tabular}{l|c|c|c|c}
\multirow{2}{*}{\begin{tabular}{l} 
Preços médios nominais dos escravos negociados em Rio Claro segundo sexo e ocupação (1861-1869) \\
\cline { 2 - 5 }
\end{tabular}} & \multicolumn{3}{|c}{ Homens } & \multicolumn{2}{c}{ Mulheres } \\
\cline { 2 - 5 } $\begin{array}{l}\text { Copeiro/Cozinheiro/ } \\
\text { engomador }\end{array}$ & 1 & 2.200 .000 & - & - \\
\hline Cozinheiro & 2 & 2.100 .000 & - & - \\
\hline Carpinteiro & 4 & 1.875 .000 & - & - \\
\hline Lavoura & 59 & 1.687 .886 & 8 & 1.501 .000 \\
\hline Servente & 1 & 1.650 .000 & - & - \\
\hline Serviço doméstico & 16 & 1633594 & 2 & - \\
\hline Alfaiate & 1 & 1.600 .000 & - & - \\
\hline Pesca & 1 & 1.600 .000 & - & - \\
\hline Ferreiro & 2 & 1.585 .000 & - & - \\
\hline Pedreiro & 1 & 1.500 .000 & - & Preço médio (réis) \\
\hline Fonte: Escrituras de compra e venda de escravos preservadas pelos Cartórios de Notas (10 e 2o) de Rio Claro. Coleta e \\
compilação dos dados próprias.
\end{tabular}

Identificamos o preço individual de apenas 20 desses escravos. Tendo em vista que os cativos cuja ocupação ou experiência foram descritas nas crônicas de suas vendas correspondem a menos de um quinto do total de indivíduos comercializados ao longo do período por nós analisado, verificamos que os indivíduos destinados à lavoura possuíam o quarto maior preço da série, ligeiramente superior $(3,2 \%)$ ao segundo grupo mais relevante, os servidores domésticos. Dentre os escravos que atingiram maior preço temos os cozinheiros e carpinteiros. Dentre os primeiros, temos os cativos Eliseu, crioulopreto de 36 anos, Ignácio, de 23 anos e Benzinho, crioulo de 19 anos originário do Piauí, todos negociados, coincidentemente, ao longo de 1869. Enquanto estes últimos foram negociados individualmente, mediante o comércio interprovincial (ambos migraram da província do RJ para Rio Claro), o primeiro foi vendido com um grupo, formado por mais quatro cativos, que também saíram do Rio de Janeiro, porém, com destino à Botucatu. No conjunto destes cozinheiros, Benzinho alcançou o maior preço, sendo vendido em dezenove de junho, ao Barão de Araraquara - possivelmente um dos mais importante escravista da região - por 2:200\$000, preço que pode ser explicado por este escravo além de ser um jovem cozinheiro, possuir habilidades de copeiro e engomador ${ }^{74}$.

Afinal, com relação aos carapinas, elegemos como arquétipo o cativo Benedito, crioulo, de 20 anos, natural de Santo Antonio. Foi vendido individualmente por Claudio A. Oliveira a Candido José de Souza, por meio do tráfico intraprovincial (Jaú $\rightarrow$ Rio Claro) por 1:600\$000.

\section{Considerações finais}

Neste artigo investigamos o tráfico interno de escravos no município de Rio Claro, cidade que pertence ao chamado por José Francisco de Camargo de Região da Baixa Paulista e que Emília Viotti da Costa tratou como uma zona relativamente nova do oeste paulista, cujo desenvolvimento, decorrente da expansão Leste-Oeste dos cafezais, fora, sobretudo, posterior a 1850.

\footnotetext{
${ }^{72}$ Calmon, Pedro. História do Brasil na Poesia do Povo. Rio de Janeiro: Edições Bloch, 1973. p. 67.

${ }^{73}$ Para uma classificação detalhada e justificada dos ofícios dos escravos no Rio de Janeiro, para um período mais recuado do que o trabalhado por nós, ver: Lima, C. A. M. Artífices do Rio de Janeiro (1790-1808). Rio de Janeiro: Apicuri, 2008.

${ }^{74}$ Todos estes registros encontram-se preservados nos arquivos do $1^{\circ}$ Cartório de Notas e Protestos de Rio Claro.
} 
Partindo deste contexto, para analisarmos este tráfico, elegemos como núcleo documental para esta empreitada 320 Escrituras de compra e venda de cativos, que abarcaram negócios envolvendo 575 pessoas mercadejadas entre 1861 e 1869. Quando analisamos estas fontes primárias manuscritas, em um primeiro momento, notamos ter sido a maior parte dos cativos transacionada em grupos de três ou mais indivíduos, nos quais os homens jovens constituíram a grande maioria. No tocante à modalidade do tráfico, apreendemos que a movimentação intraprovincial foi a mais significativa (envolvendo a venda de 174 cativos), seguida das transações locais, que envolveram 161 pessoas e, interprovinciais responsáveis por 77 indivíduos terem se deslocado de outras províncias (sobretudo RJ e MG) para o fado das fazendas de café Rio-clarenses. Além disso, quando consideramos a classificação dos cativos de acordo com a origem, aferimos que os crioulos corresponderam a quase $80 \%$ do total dos cativos com procedência por nós identificada. Enquanto estes foram vendidos, sobretudo, mediante o comércio intraprovincial, os "de nação" foram vendidos, mormente, mediante o tráfico local.

Em seguida, além de termos constatado que as entradas em Rio Claro, tanto pelo tráfico intraprovincial, quanto pelo interprovincial foram bastante mais significativas que as saídas deste município, percebemos que quando agrupamos os escravos africanos ("de nação") com idade de até 45 anos, quase $60 \%$ desses encontravam-se no intervalo etário de 31 a 45 anos - conjunto no qual os homens correspondiam a 72,4\%. Em contrapartida, quando consideramos os dados concernentes aos cativos crioulos, notamos a ocorrência de expressivo número de crianças e jovens $(33,3 \%$ com idade inferior a 15 anos) separado de suas famílias e vendido a outros proprietários. Já os crioulos com idade inferior a 46 anos, apenas 5\% encontram-se na faixa etária de 31 a 45 anos, enquanto $61,6 \%$ possuíam entre 15 e 30 anos (desses $73 \%$ eram homens).

Por fim, dentre outras coisas, associamos a caracterização do tráfico, com a idade, o sexo e o preço médio nominal dos cativos. Ao fazermos isso, visualizamos distinções patentes. Por exemplo, se centrarmos atenção na fatia etária que engloba a maior parte dos indivíduos vendidos mediante as três formas de tráfico, 15 e 30 anos, temos o seguinte resultado: no comércio local, enquanto os homens eram vendidos, em média, por 1:611\$068 as mulheres foram transacionadas por 1:489\$221. Já no tráfico intraprovincial, os homens foram vendidos com um preço $15,6 \%$ superior ao das mulheres e, no interprovincial, os primeiros alcançaram um preço 12,5\% maior. Outrossim, apreendemos, também, que os homens e as mulheres alienados por intermédio das vendas entre diferentes províncias possuíam preços superiores ao dos escravos e escravas comerciados por meio dos outros dois caminhos. 